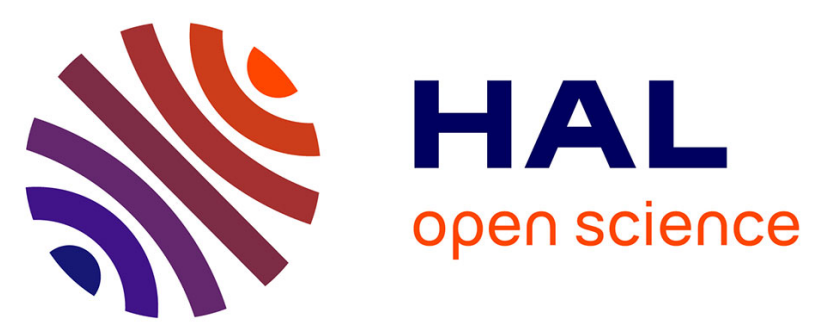

\title{
Transfer and uptake of polychlorinated dibenzo-p-dioxins and furans (PCDD/Fs) and polychlorinated biphenyls (PCBs) into meat and organs of indoor and outdoor reared pigs.
}

\author{
Martin Rose, Alwyn R Fernandes, Chris Foxall, Alan Dowding
}

\section{To cite this version:}

Martin Rose, Alwyn R Fernandes, Chris Foxall, Alan Dowding. Transfer and uptake of polychlorinated dibenzo-p-dioxins and furans ( $\mathrm{PCDD} / \mathrm{Fs}$ ) and polychlorinated biphenyls (PCBs) into meat and organs of indoor and outdoor reared pigs.. Food Additives and Contaminants, 2011, pp.1. 10.1080/19440049.2011.635346 . hal-00762897

\section{HAL Id: hal-00762897 \\ https://hal.science/hal-00762897}

Submitted on 9 Dec 2012

HAL is a multi-disciplinary open access archive for the deposit and dissemination of scientific research documents, whether they are published or not. The documents may come from teaching and research institutions in France or abroad, or from public or private research centers.
L'archive ouverte pluridisciplinaire HAL, est destinée au dépôt et à la diffusion de documents scientifiques de niveau recherche, publiés ou non, émanant des établissements d'enseignement et de recherche français ou étrangers, des laboratoires publics ou privés. 


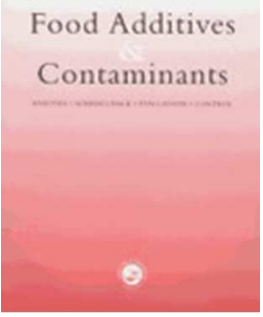

\section{Transfer and uptake of polychlorinated dibenzo-p-dioxins and furans (PCDD/Fs) and polychlorinated biphenyls (PCBs) into meat and organs of indoor and outdoor reared pigs.}

\begin{tabular}{|c|c|}
\hline Journal: & Food Additives and Contaminants \\
\hline Manuscript ID: & TFAC-2011-306.R1 \\
\hline Manuscript Type: & Original Research Paper \\
\hline Date Submitted by the Author: & 19-Oct-2011 \\
\hline Complete List of Authors: & $\begin{array}{l}\text { Rose, Martin; FERA } \\
\text { Fernandes, Alwyn; FERA } \\
\text { Foxall, Chris; University of East Anglia, School of Environmental Sceinces } \\
\text { Dowding, Alan; Food Standards Agency }\end{array}$ \\
\hline Methods/Techniques: & Chromatography - GC/MS, Risk assessment, Health significance \\
\hline Additives/Contaminants: & Dioxins, Dioxins - TEQs, Environmental contaminants \\
\hline Food Types: & Meat, Animal feed \\
\hline Abstract: & $\begin{array}{l}\text { This study was designed to investigate how and to what extent PCDD/Fs } \\
\text { and PCBs are transmitted from exposure sources to porcine muscle and } \\
\text { other tissues derived from pigs. The experimental approach involved two } \\
\text { longitudinal studies in which indoor and outdoor pigs were reared to } \\
\text { market readiness using typical animal husbandry practices; closely } \\
\text { matched samples of soil, feed, bedding, meat etc., were collected and } \\
\text { analysed for PCDD/Fs and PCBs. The total PCDD/F + PCB WHO-TEQs in } \\
\text { pig liver were much higher than in meat and kidney samples from the } \\
\text { same animals and exceeded the current relevant EU maximum limits ( } 6 \mathrm{ng} \\
\text { PCDD/F-TEQ/kg fat). Liver samples were also characterised by much lower } \\
\text { PCB contributions to the total TEQ than for the corresponding meat and } \\
\text { kidney samples, and by a predominance of many of the hepta- and octa- } \\
\text { substituted PCDD/Fs. At ages approaching market readiness, TEQ values } \\
\text { in meat samples from outdoor pigs tended to be slightly higher than those } \\
\text { from comparable ages in the indoor programme, possibly due to additional } \\
\text { intake from soil. Biotransfer factors (BTFs) were derived for each of the } 39 \\
\text { PCDD/F and PCB congeners measured. Interpretation of the findings } \\
\text { focused particularly on trends in four selected congeners, namely } 2,3,7,8- \\
\text { TCDD, } 2,3,4,7,8-P e C D F, \text { PCB } 153 \text { and PCB } 169 \text {. Increases in the BTF for } \\
\text { PCB } 169 \text { in the pig rearing programmes were noticed when the diet } \\
\text { changed from being dominated by sow's milk to feed. Much higher }\end{array}$ \\
\hline
\end{tabular}


transfer factors for many of the more heavily chlorinated PCDD/Fs (e.g. $2,3,4,7,8$-PeCDF) were found in liver compared with meat or kidney samples from the same animals. Soil consistently accounted for at least $30 \%$ of input for many hexa- or higher chlorinated PCDD/Fs, while rarely representing more than $10 \%$ of the total intake.

\section{SCHOLARONE $^{\text {m }}$ \\ Manuscripts}




\title{
Transfer and uptake of polychlorinated dibenzo-p-dioxins and furans (PCDD/Fs) and polychlorinated biphenyls (PCBs) into meat and organs of indoor and outdoor reared pigs
}

\author{
Martin Rose ${ }^{1^{*}}$, Alwyn Fernandes $^{1}$, Chris Foxall $^{2}$ and Alan Dowding ${ }^{3}$. \\ ${ }^{1}$ The Food and Environment Research Agency, Sand Hutton, York YO41 1LZ, UK. \\ ${ }^{2}$ School of Environmental Sciences, University of East Anglia, Norwich NR4 7TJ, UK \\ ${ }^{3}$ Food Standards Agency, Aviation House, 125 Kingsway, London W2CB 6NH, UK.
}

\begin{abstract}
This study was designed to investigate how and to what extent PCDD/Fs and PCBs are transmitted from exposure sources to porcine muscle and other tissues derived from pigs. The experimental approach involved two longitudinal studies in which indoor and outdoor pigs were reared to market readiness using typical animal husbandry practices; closely matched samples of soil, feed, bedding, meat etc., were collected and analysed for PCDD/Fs and PCBs. The total PCDD/F + PCB WHO-TEQs in pig liver were much higher than in meat and kidney samples from the same animals and exceeded the current relevant EU maximum limits (6 ng PCDD/F-TEQ/kg fat). Liver samples were also characterised by much lower PCB contributions to the total TEQ than for the corresponding meat and kidney samples, and by a predominance of many of the hepta- and octa-substituted PCDD/Fs. At ages approaching market readiness, TEQ values in meat samples from outdoor pigs tended to be slightly higher than those from comparable ages in the indoor programme, possibly due to additional intake from soil. Biotransfer factors (BTFs) were derived for each of the 39 PCDD/F and PCB congeners measured. Interpretation of the findings focused particularly on trends in four selected congeners, namely 2,3,7,8-TCDD, 2,3,4,7,8-PeCDF, PCB 153 and PCB 169. Increases in the BTF for PCB 169 in the pig rearing programmes were noticed when the diet changed from being dominated by sow's milk to feed. Much higher transfer factors for many of the more heavily chlorinated
\end{abstract}


PCDD/Fs (e.g. 2,3,4,7,8-PeCDF) were found in liver compared with meat or kidney samples from the same animals. Soil consistently accounted for at least $30 \%$ of input for many hexa- or higher chlorinated PCDD/Fs, while rarely representing more than $10 \%$ of the total intake.

Keywords: biotransfer factors, bioconcentration factors, indoor and outdoor pigs.

\section{Introduction}

Polychlorinated dibenzo-p-dioxins and furans (PCDD/Fs or 'dioxins') and polychlorinated biphenyls (PCBs) are ubiquitous environmental contaminants. They are highly lipophilic and human exposure is primarily through the consumption of foods rich in animal and marine fats and oils. The transmission of dioxins and PCBs from pasture, soils and feed into cow's milk and beef has been the focus of a number of studies (Thomas et al, 1999; Bluthgen et al, 1995; Schuler et al, 1997; McLachlan, 1993; Slob et al, 1995; Stevens and Gerbec, 1998; Chang et al, 1989; Goldman et al, 1989) and attempts have been made to model their transfer through the food chain (Douben et al, 1997; McLachlan, 1997; Harrad and Smith, 1997). By comparison few data are available on the transmission of dioxins and PCBs into other animal produce, although there have been some laboratory studies on the bioavailability of PCDD/Fs from highly contaminated soil by pigs (Wittsiepe et al, $2004 \&$ 2007). The first paper in this series (Fernandes et al, 2011) described the general approach that we have used to investigate the movement of dioxins and PCBs through the food chain; this paper focuses on indoor and outdoor reared pigs reared under normal farm conditions.

Congener specific studies involving farm animals and various wildlife species have shown that the bioavailability of dioxins and PCBs from environmental and dietary sources is congener dependent and generally reduces with increased chlorination. Uptake rates appear both congener and tissue dependent and duration of exposure plays a role in the distribution of contaminants between tissues. Congener profiles and concentrations in tissues have been shown to reflect feeding habits, and the metabolic 
characteristics of particular species. Comparisons of PCBs congener profiles in various biota have suggested that the more toxic dioxin-like congeners may preferentially accumulate. TEQ profiles also appear to vary considerably from species to species (Fernandes et al, 2011).

This study aimed to (i) obtain full range of bio transfer factors (BTFs) for the congeners measured in pigs, (ii) to obtain full TEQ values for meat and food from pigs reared using standard but controlled animal husbandry practices and to correlate the results with surveillance data (iii) to evaluate potentially significant sources of dietary exposure to these contaminants and (iv) to provide a more comprehensive basis on which to validate and optimise predictive environmental pathway and exposure models in this area.

\section{Materials and methods \\ Rearing and Sampling}

Selected animals were reared to market readiness using typical commercial animal husbandry practices. During this period, closely matched sets of soil, feed, grass, sows' milk and meat from the pigs that were reared (including offal) were collected and analysed for dioxins and PCBs.

Summaries of the outdoor and indoor rearing and sampling schedules are shown in Figures 1 and 2, and details of the type, supply periods and feed consumption patterns for the sow and the growing pigs are given in Figures 3 and 4 for the outdoor sow and growing pigs respectively and Figures 5 and 6 for the indoor sow and growing pigs respectively.

Outdoor pigs

Rearing schedule

The pigs were reared outdoors at Easton College, Norfolk, England, as part of the normal commercial activities of the farm. The sows used were a Landrace/Duroc/Large White hybrid (LR 25\%/DR 25\%/LW 50\%). The boar was a Large White and thus the offspring were also hybrids (LR 12.5\%, DR $12.5 \%$ and LW $75 \%$ ). Conception was by artificial insemination and the 
detailed rearing schedule is shown in Figure 1. The typical time required from conception to market readiness is 8-9 months; with three main stages, namely gestation (four months), lactation (one month), and rearing and finishing (three-four months).

Although only one sow and her offspring were used for the project, a second pregnant sow was also identified as a back-up. Both pregnant sows were kept on the same field during the period of gestation. Following the birth of the piglets, the two sows and their offspring were transferred to separate outdoor enclosures (arcs) and both sets of piglets were closely observed for signs of distress or ill-health.

The sow selected for the study gave birth to ten piglets (five female), after a gestation period of 115 days. On the basis of health and strength, eight of the newly born animals were selected for the rearing programme and given identification tags.

The young piglets were weaned from the sow after 25 days. They were weighed on that day and again at 7 weeks old; the mean weights of the young pigs at weaning and at 7 weeks were $7.2 \mathrm{~kg}$ and $19.2 \mathrm{~kg}$ respectively. To avoid possible stress to the growing pigs no further weighings were carried out. Immediately following weaning, the sow and two of the piglets (aged 25 days) were slaughtered. The remaining eight piglets were transferred to an outdoor 'growing' pen. Two of these were slaughtered aged 81 days, and a further four were slaughtered aged 142 days, having reached desired market weight of 95 $100 \mathrm{~kg}$.

The sow and her young were housed in a traditional corrugated metal arch following birth. After weaning, the pigs were kept in an outdoor enclosure fenced constructed from galvanised metal sheets. No incidents of ill health were observed during the programme. Details of routine veterinary inputs are provided in Table 1.

\section{Samples collected}


The sampling schedule for outdoor pigs is detailed in Figure 1. During lactation, milk letdown to the piglets occurs every 60 - 90 minutes and lasts for 15-20 seconds only. This short letdown period combined with the fact that modern breeds of pigs tend to be highly stressed animals and their power and potential aggressiveness, made the collection of milk from an unrestrained pig difficult and it was not done. Furthermore, obtaining milk from outdoor sows is recognised to be considerably more difficult to obtain than from indoor equivalents as the outdoor sows find restraint far more stressful.

\section{Feed intake}

Given the requirement to adopt husbandry techniques typical of the pig industry it was not feasible to measure the precise daily feed intake by the sow and each offspring, and reliable estimates were used instead.

\section{Feed- outdoor sow}

Prime rolls were provided up to the time of insemination, and lactating nuts were provided for the first three weeks of gestation, followed by prime rolls again for a further twelve weeks (Figure 1). For the nine days prior to the birth of the piglets, lactating nuts were again provided to ensure that sufficient milk would be available. Overall, prime rolls were provided for 84 days (72\%) of the gestation period of 116 days. Daily feed intake during this time remained fairly constant, ranging from $1.8-2.7 \mathrm{~kg} \cdot \mathrm{d}^{-1}$ (mean $2.6 \mathrm{~kg} \cdot \mathrm{d}^{-1}$ ).

Following the birth of the piglets, the feed provided to the sow reverted back to prime rolls and feed intake increased from $2.3 \mathrm{~kg} \cdot \mathrm{d}^{-1}$ to $9.5 \mathrm{~kg} \cdot \mathrm{d}^{-1}$ after 17 days. Intake remained constant until weaning one week later and mean feed intake by the sow over this period was $4.4 \mathrm{~kg} \cdot \mathrm{d}^{-1}$. Between the date of insemination and slaughter, the sow consumed $332 \mathrm{~kg}$ of prime rolls and 69 $\mathrm{kg}$ of lactating nuts. Total feed intake was $401 \mathrm{~kg}$, equivalent to an average of $2.9 \mathrm{~kg} \cdot \mathrm{d}^{-1}$ over the 139 day period. 


\section{Feed- outdoor young pigs}

Eight young pigs from the litter produced by a single sow were monitored; two were slaughtered at 25 days old, a further two at 81 days and the remaining four at 142 days (standard market weight). In order to raise young pigs to market readiness in an outdoor environment, we followed normal practice and used three different types of feed. Startercare Easiween was provided to facilitate the transition from mother's milk to solid food and was given for a relatively short period either side of weaning. In contrast, Startercare Maxecreep represents the major source of feed during the overall rearing period, being provided for a total of 94 days. Daily consumption of this feed rose steadily from $0.2 \mathrm{~kg} \cdot \mathrm{d}^{-1}$ to $2.1 \mathrm{~kg} . \mathrm{d}^{-1}$ after four months later. The final feed (Sovereign pellets) was provided for 13 days immediately prior to slaughter, at which point daily consumption levels had reached $2.4 \mathrm{~kg} \cdot \mathrm{d}^{-1}$.

Indoor pigs

Rearing schedule

The sows and boar used were of an identical breed to those used for the outdoor pig programme. Although we used only one sow and her offspring, two other pregnant sows on the farm were also identified as back up. All three sows were kept under the same conditions and were given the same feed during the period of gestation. One sow was artificially inseminated and subsequently gave birth to ten young piglets ( 8 male and 2 female) after a gestation period of 115 days. Two of the piglets were slaughtered on the day of birth, the remaining piglets were weaned from their mother aged 27 days. After weaning, the mother and two further piglets were slaughtered. Two more piglets were slaughtered aged 90 days and the remaining four were slaughtered aged 179 days at market weight (around 95-100kg). The young pigs were weighed at birth and at weekly intervals during the suckling period and agreed with the expected growth pattern. Details of routine veterinary inputs to the sow and the growing pigs are shown in Table 1. No instances of ill health were recorded during the programme.

The sow and offspring were housed in buildings that have been used to rear pigs for the last 20 years or so. The walls were rendered concrete and the 
floors were concrete overlaid with bitumen blocks to provide improved thermal insulation. Interior partitions were made of untreated plywood and the sows farrowed in metal pens which are pressure washed with a viral disinfectant (Virkon) between each batch of pigs. An overview of the key features of the rearing programme is given in Figure 2.

\section{Samples collected}

In view of the difficulties in obtaining milk samples for the outdoor pigs, it was decided to use a combination of stresnil and oxytocin from the outset in order to facilitate milk release. This enabled the first of the planned samples to be successfully collected soon after the mother gave birth, but despite repeated attempts it was not possible to obtain later samples. Milk from one of the back-up animals sow was however obtained on the same date as that from the project sow, and a further, smaller sample was obtained from this second sow 12 days later.

Feed - indoor sow

Only one type of feed (Challenger nuts) was given to this sow throughout the programme, in contrast to the regime used for the outdoor sow. Both represent common farm practice. Daily feed intake was approximately 2.5 $\mathrm{kg} \cdot \mathrm{d}^{-1}$ during gestation and was reduced to around $1.4 \mathrm{~kg} \cdot \mathrm{d}^{-1}$ around the time the piglets were born. After the birth of the piglets, daily feed consumption increased reaching a maximum of $5.4 \mathrm{~kg} \cdot \mathrm{d}^{-1}$. This level was maintained until the young pigs were weaned and the sow slaughtered 20 days later. Mean daily feed intake for the sow during the period from the birth to slaughter was $4.5 \mathrm{~kg} \cdot \mathrm{d}^{-1}$, similar to that for the outdoor sow $\left(4.4 \mathrm{~kg} \cdot \mathrm{d}^{-1}\right.$, see above). From insemination to the date of slaughter, the sow consumed around $409 \mathrm{~kg}$ feed, an average daily intake of $2.9 \mathrm{~kg} . \mathrm{d}^{-1}$, which compares with $401 \mathrm{~kg}$ and 2.9 $\mathrm{kg} \cdot \mathrm{d}^{-1}$ respectively for the outdoor sow.

Feed - indoor young pigs

The indoor programme involved the rearing and monitoring of ten young pigs that constituted the litter of a single sow. Of the ten animals, two were slaughtered on the day of birth, two straight after weaning (aged 27 days) and 
a further two at 90 days old. The remaining four were slaughtered aged 179 days having reached the desired market weight. They were reared to market readiness using two main types of feed, namely Startercare Maxecreep and Sovereign pellets. The indoor-reared piglets were weaned onto solid food using Startercare Maxecreep rather than the Easewean feed used in the outdoor programme, but both reflect common farming practice.

A summary of the type, periods and daily intake of feed is given in Figure 6 , which also shows that a third feed (OP Pellets) were provided in the last week of the programme. This feed is similar to Sovereign pellets, but sourced from a different manufacturer. The feeds were provided for 73,84 and 5 days respectively. By the time the animals had reached market weight, daily and total feed intake had reached $2.4 \mathrm{~kg} \cdot \mathrm{d}^{-1}$ and $192 \mathrm{~kg}$ respectively.

For the animals slaughtered prior to reaching market weight, the patterns of feed intake were different; details of the four groups of animals (slaughtered at birth, 27, 90 and 179 days respectively) are shown in Table 2.

\section{Analytical}

The analytical methodology used was based on that reported previously (Fernandes et al, 2004). Briefly, the sample was freeze-dried and ground, and thoroughly homogenised. An aliquot was fortified with known amounts of surrogate $\left({ }^{13} \mathrm{C}_{12}\right.$-labelled) analogues of target analytes and was exhaustively extracted using mixed organic solvents. The extract was purified by acid hydrolysis followed by adsorption chromatography. Ortho-PCBs, non-ortho$\mathrm{PCBs}$ and $\mathrm{PCDD} / \mathrm{Fs}$ were segregated into three separate fractions. Each fraction was concentrated and further cleaned up before the inclusion of additional ${ }^{13} \mathrm{C}_{12}$-labelled internal sensitivity standards. Final determination was by high resolution gas chromatography with either low resolution mass spectrometric detection (ortho-PCBs) or high resolution mass spectrometric detection (non-ortho-PCBs and PCDD/Fs). All 17 PCDD/Fs and PCBs assigned a WHO-TEF, the ICES 7 PCBs and some additional PCBs were measured (as listed in the results tables such as the first column in Table 4). All analytical data were assessed for compliance with the analytical quality 
assurance criteria prescribed in EU legislation for control of these contaminants in food (European Commission, 2002), and the demands of ISO 17025 accreditation. Further validation and quality assessments were made by participation in interlaboratory comparison exercises including those run by the Folkehelsa Institute for Public Health in Norway (eg. National Institute of Public Health, 2005).

\section{Results and discussion}

\section{$P C B$ and $P C D D / F$ concentrations in pigs}

A summary of several key results is given in Table 3 (a) for the indoor and 3 (b) for the outdoor pigs. Where more than one animal was available, samples were taken from one of them at random. The TEQs for the meat samples generally decline with the age of the pig and are lower than those in the feed. This contradicts the hypothesis that indoor pigs accumulate PCDD/Fs and PCBs in their meat through ingestion of feed, at least while they are still growing. Two samples of sows' milk were obtained immediately after the birth of piglets, and the TEQs for these were below those calculated for all of the feed and most of the meat samples. A relatively high TEQ was found for pigs' liver, approximately ten times greater than the corresponding values for meat and kidney samples from the same animal. The liver result was also distinctive in the relatively low PCB contribution to the total TEQ and raised levels for many of the hepta- and octa-substituted PCDD/Fs.

At ages approaching market readiness, the TEQ values for outdoor reared pigs tended to be slightly higher than those from samples at comparable ages in the indoor programme. This may be due to additional PCDD/F and PCB intake from soil, but note that the soil samples analysed were well within the range expected of rural background levels.

\section{Sources and uptake routes}

The transfer of PCBs and PCDD/Fs into pigs may occur by either: ingestion of feed, soil, soil organisms, vegetation or water (in the case of young pigs, sow's milk may be an important uptake route); inhalation; dermal uptake 
from soils; or from contact with farm buildings, bedding etc. (Fernandes et al, 2011)

On the basis of studies of other farm-reared animals (McLachlan 1993); the ingestion of feed would be expected to constitute the dominant route. But there is a tendency for pigs reared outdoors to wallow in shallow mud baths and to have a generally high degree of contact with the soil, which raises the possibility that the uptake of PCDD/Fs and PCBs through the skin could also be an important factor for these animals. The relative significance of the various routes by which PCDD/Fs and PCBs can be taken up into pig tissues is likely to be influenced by a wide range of ancillary factors which include breed, sex, rearing conditions, type of feed and feed intake, state of health, age, and stage of breeding season.

A small number of controlled exposure studies have examined the levels of contamination in pig tissues following ingestion of specially formulated diets containing varying concentrations of PCDD/Fs and PCBs. Borchard et al (1976) investigated the uptake of PCBs by rearing pigs following ingestion of feed to which Aroclor 1254 had been added. The transfer of PCDD/Fs from spiked milk to arterial blood in pigs was studied by Rychen et al (2002). Other investigations focused on the concentrations of contaminants in pigs reared on sewage sludge amended soils known to be contaminated with Aroclors (Hansen et al 1981) or following exposure to contaminated feed (Bernard et al 2002). Such studies are useful for our understanding of pathways and uptakes of PCDD/Fs and PCBs in pigs but contaminants may behave differently at high concentrations compared with conventional diets and animal husbandry techniques.

Although many studies have reported data on the levels of PCDD/Fs and PCBs in samples of pork meat destined for human consumption (e.g. Ryan et al 1985; Beck et al 1989; Furst et al 1990; Liem and Theelen 1997; Lorber et al 1997), no simultaneous analyses were made of the contaminant concentrations in feed and there are no systematic investigations into the levels and sources of $\mathrm{PCDD} / \mathrm{Fs}$ and $\mathrm{PCBs}$ in pigs reared on conventional diets. 
PCDD/F and PCBs may also be ingested through the incidental consumption of soil during foraging due to the characteristic rooting and foraging behaviour of outdoors reared pigs (Fries et al 1982). This is supported by the work of Jacobs et al (1981) which demonstrated that pigs confined to soil containing polybrominated biphenyls (PBBs) accumulated higher levels in their fat than cattle confined to fields with similar soil concentrations. Wittsiepe et al, (2004 \& 2007) have shown that the bioavailability of PCDD/Fs from highly contaminated soil ingested by Goettingen minipigs is relatively low compared with bioavailability from spiked feed.

The rate of soil ingestion may be related to factors such as the nature of the pasture, time of year, weather conditions and the level and type of feed provided. One study of seasonal variations (Healy 1967) showed that soil ingestion rates by animals reared on grazing pastures were greatest in winter. A later study by Healey and Drew (1970), which explored how soil intake varied with feeding regime, demonstrated that animals allowed to graze on root crops such as swedes during the winter months ingested considerably more soil than those grazed on pastureland. Mean soil ingestion rates measured over an eleven-week period for animals on swedes and those on

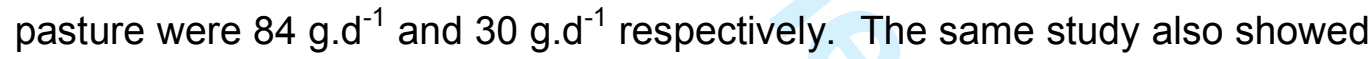
that soil ingestion by pigs varied considerably between individual animals and increased substantially during wet conditions.

Age and sex of animals can also influence soil uptake rates as demonstrated in a study by Lorber et al (1997) in which it was found that boars accumulated higher levels of PCDD/Fs and PCBs than sows reared under the same conditions, and that concentrations in older boars were generally greater than in younger animals. Although soil ingestion is likely to be relatively small compared with total feed, the known persistence of PCDD/Fs and PCBs in the surface layers means that soils can make a significant contribution to overall contaminant intakes, and could easily be a significant problem if contaminated slurry or other material has recently been spread on the land (Hansen et al 1981). Dioxins have been recognised as a potential contaminant following uncontrolled burning in the vicinity of farmland following the pyres used to 
dispose of animal carcases during a Foot and Mouth disease outbreak in the United Kingdom (Rose et al, 2005).

Piglets are born with a body burden of PCDD/Fs and PCBs as a result of in utero transfer of contaminants. Further sources can include transfer of PCDD/Fs and PCBs directly into young pigs via sow's milk for suckling pigs. Young pigs are weaned from their mother at four weeks old and rely on commercial feed thereafter, and so samples taken from around four weeks and earlier are likely to reflect input from the mothers' milk whereas later the feed will have increasing influence.

Opportunities for comparisons between animal species and tissue type are limited by the lack of data. One study in the Netherlands (Liem and Theelen 1997) involved the collection of chicken, horse, mutton, goat and pork samples (animal fat and liver) from slaughterhouses during 1990. The results indicated that the total concentrations of PCDD/Fs and PCBs in pork fat samples were considerably lower than those in beef and chicken. By contrast, levels in pork liver samples were substantially higher than those in beef and chicken livers, but well below those typical of goat and horse.

In a similar Belgian survey (Focant et al 2002), a range of lamb, beef, pork, chicken and horse meat samples were collected from slaughterhouses or retail outlets in 2000 and 2001. Total concentrations of PCDD/Fs plus PCBs in pork were found to be substantially lower than in any of the other types of meat. Few data are available on the relative levels of PCDD/Fs and PCBs in different pig tissues. On the basis of studies in other farm animals such as cattle (Thomas et al 1999), it might be expected that the levels of these contaminants in pig's liver would be higher than in a corresponding meat sample from the same animal. The study by Liem and Theelen (1997), which reported mean concentrations of 17 and 0.6 (ng WHO-TEQ/kg fat) in liver and meat tissues from the same animal, not only confirms this expectation but also suggests that liver may be a particular target organ for PCDD/Fs and PCBs in the pig, in common with findings for sheep (Fernandes et al, 2010; Rose et al, 2010). The investigation 
of PCDD/Fs by Goettingen minipigs also demonstrated accumulation predominantly in the liver (Wittsiepe et al, 2004).

The study of PCDD/F concentrations in retail foodstuffs from the Netherlands (Liem and Theelen 1997) demonstrated that the congener patterns in pig liver samples were significantly different from those in meat samples from the same animal. As shown by Bernard (2002), the higher chlorinated congeners (especially the hepta- and octa-substituted) were found to predominate in pig liver samples. The shift in PCDD/F congener patterns between liver and meat samples was quite marked. By way of comparison, a similar shift in PCDD/F patterns was also found in sheep (Rose et al, 2010) and goats but, interestingly, no such differences were found in chickens (Fernandes et al, 2010). Overall, the results of these studies suggest that the uptake and transfer of PCBs and $\mathrm{PCDD} / \mathrm{Fs}$ in pigs may be different to those in other farm animals.

\section{Comparisons with previous data}

Meat

A comparison of the mean total TEQ concentrations in pig meat from the present study with previous survey data is given in Table 3 (c). The total TEQ data for the seven studies listed in the table show a concentration range of 0.08 - $4.2 \mathrm{ng}$ TEQ. $\mathrm{kg}^{-1}$.fat with a mean value of $1.1 \mathrm{ng}$ TEQ. $\mathrm{kg}^{-1}$.fat. The studies reporting the lowest concentrations (0.08 and $0.19 \mathrm{ng}$ TEQ. $\mathrm{kg}^{-1}$.fat respectively) both treated congener concentrations below the limit of detection as equal to zero.

An examination of the total TEQ concentrations from the present study presented in Table 3 (c) suggests that they are consistent with previously published data. For example, the overall mean value $\left(0.77 \mathrm{ng}\right.$ TEQ. $\mathrm{kg}^{-1}$.fat $)$ for the meat samples analysed in the current study falls within the range of mean values previously reported. However, the contribution of dioxin-like PCBs to the total TEQ (range 37-74\%; mean 53\%) appears to be greater than that from previous surveys (4.4-40\%; mean $21 \%$ ).

Liver and kidney 
A comparison of the total TEQ concentrations in liver and kidney samples from the present study with previous survey data is given in Table 3 (d). The total TEQ data for the first three studies listed show a concentration range of 8.8-

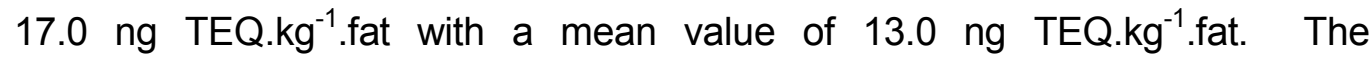
corresponding values (range 8.9-20.6; mean $14.8 \mathrm{ng} \mathrm{TEQ.} \mathrm{kg}^{-1}$. fat) from the present study agreet with previously reported data. The mean contribution of PCBs to total TEQs in the present study (14\%) falls at the lower end of the range $(12-28 \%)$ reported from earlier surveys. The samples analysed in the earlier UK studies (MAFF 1997: FSA 2000) were of offal and hence would have included some other tissues in addition to pig's liver. The table also indicates that the total TEQ concentrations $\left(0.88 \mathrm{ng} \mathrm{TEQ} . \mathrm{kg}^{-1}\right.$.fat) in kidney samples collected during the present project are much lower than in the liver samples from the same animals.

BTFs for Indoor pigs Intakes of feed and milk

The mean daily feed intakes of the growing pigs were calculated from the feed consumption profile. For example, two of the pigs were each estimated to have consumed a total of $24.4 \mathrm{~kg}$ feed over a 28 day period, equivalent to a mean daily intake of $0.87 \mathrm{~kg} \cdot \mathrm{d}^{-1}$. Two of the pigs were only provided with feed during the last ten days of their lives. Total consumption for this period amounted to $1.0 \mathrm{~kg}$ which, averaged over the lifetime of the animals $(27$ days), gave a mean daily intake for the period of $0.04 \mathrm{~kg}^{-1}$. In order to compare with growing pigs, the daily consumption of feed by the sow was also calculated for the 28 day period immediately prior to the slaughter of the animal using the consumption profile for growing pigs, and was calculated to be $4.40 \mathrm{~kg} \cdot \mathrm{d}^{-1}$.

Milk production by a sow depends upon factors including the weight of the animal, breeding history, size of litter and stage of lactation (Agricultural Research Council 1967; BSAS 2003). For a sow of comparable weight to those used here $(200 \mathrm{~kg})$, daily milk production typically commences at around three litres per day when the offspring are born, rising to eight litres per day after a week. Milk production tends to peak at around 9.5 litres per 
day after 21 days (BSAS, 2003; Dunning 2003; Whittemore 2003). Litter size may also influence the volume of milk produced by a sow, and the most common litter size for the breed of animals used in the project was ten animals. In the case of the indoor rearing programme, the sow was only providing milk for eight piglets because two were slaughtered at birth.

To estimate levels of milk production by pigs we used the relationship between total weight gain of a litter and milk yield of the sow i.e.

Milk yield per day $=4 \times$ total weight gain by litter per day (BSAS 2003)

During the suckling period the growing animals were weighed at regular intervals. Using these data, the mean weight gain per animal over the 27 days was found to be $5.5 \mathrm{~kg}$, which was equivalent to a total weight gain by the litter ( 8 animals) of $44 \mathrm{~kg}$. The mean daily milk production by the sow was calculated at 6.52 litres per day; each of the eight piglets was therefore consuming an average of 0.82 litres per day over the 27 day suckling period.

\section{Intake flux and BTFs}

Intake details were combined with data on concentrations of PCDD/F and PCB congeners to calculate BTFs for selected samples using a standard method (Fernandes et al, 2011). To obtain the numerator for each BTF the congener concentration in the meat sample was calculated on a fat weight basis (Table 4 ).

Piglets at birth showed a body burden as a result of in utero transfer. Although this was similar in magnitude to other samples on a concentration basis, given the low weight at birth, the impact of this overall contribution became less important as the animals gained weight, and since it was broadly equivalent for all animals, it was not factored into subsequent calculations.

Sets of congener specific input fluxes for each possible PCDD/F and PCB source were derived by multiplying the whole weight concentrations by the corresponding daily intakes. The third to fifth columns in Table 4 show these 
calculations for feed, while the sixth to eighth do the same for milk (assuming a litre weighs one kilogram). For example, 2,3,7,8-TCDD in feed:

$$
0.025 \mathrm{ng} \cdot \mathrm{kg}^{-1} \times 0.04 \mathrm{~kg} \cdot \mathrm{d}^{-1}=0.001 \mathrm{ng} \cdot \mathrm{d}^{-1}
$$

The final step in obtaining BTFs was to divide each congener level in meat by the sum of the corresponding input fluxes for feed and milk. For 2,3,7,8TCDD the calculation was:

\begin{tabular}{ccc}
0.05 & 0.05 \\
\hdashline $0.001+0.005$ & $=$ & -0.006
\end{tabular}

The right hand column of Table 4 lists the BTFs for all 39 PCDD/F and PCB congeners and shows values ranging from 3.27 to 1806 . The range of BTF values in Table 4 implies differences in ease with which congeners are transferred and accumulated in the meat sample. Care must be taken where some samples contained concentrations around or below the limit of determination for the analysis since this may give an artificial impression of robustness for the BTF.

A similar process was conducted for eight indoor pig meat, liver or kidney samples. The relative contribution of different sources (e.g. milk or feed) to the total input flux was calculated. For instance, for a sample of meat from one of the young piglets, the percentages for congener 2,3,7,8-TCDD were:

$$
\begin{array}{lll}
\text { Feed } 0.0010032 / 0.00601832= & 16.67 \% \\
\text { Milk } 0.00501512 / 0.00601832= & 83.33 \%
\end{array}
$$

Similar calculations were also carried out on totals across all 39 congeners.

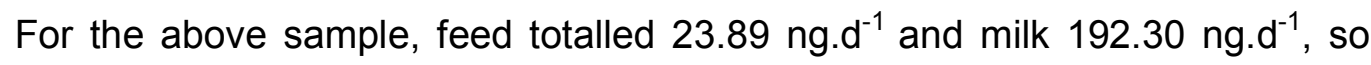
the relative contribution from feed was $11.05 \%$.

The complete set of congener BTFs for the eight indoor pig samples is given in Table 5. BTFs for four selected congeners chosen to reflect a breadth of 
chemical properties are highlighted for discussion in more detail and to show changes over time. They are shown in Table 6 and are discussed in more detail below. The table also includes average BTFs for all 39 congeners to set the values for the four congeners in a wider context, and the BTFs for all 39 congeners have been ranked ( $1=$ highest, $39=$ lowest $)$. These ranks were used for evaluating relative differences in the uptake of congeners between foodstuffs and over time.

Table 6 shows that the meat BTFs decline in magnitude during the rearing programme. This trend reflects the tendency for concentrations of PCDD/F and PCB levels to show a small decrease in meat with age, while intakes and consequently input fluxes increase. Tables 4 and 5 indicate that, across all 39 congeners, the total input flux at 27 days was dominated by sow's milk, whilst for all later samples the only source was feed. The only consistent effect associated with this change was for PCB 169, where the meat BTFs became higher (relative to other congeners) once feed was the sole source. There were also signs of similar increases for some of the higher chlorinated PCDD/Fs (e.g. 1,2,3,4,6,7,8-HpCDF) and reductions for ortho PCBs.

Of the four selected congeners, PCB 153 generally had the highest BTF into indoor pig meat and 2,3,7,8-TCDD the lowest. The ranking of the four congeners for the kidney sample was similar to that for meat from animals of the same age. For liver PCB 153 was less prominent and 2,3,4,7,8-PeCDF was more prominent. The BTFs in Table 5 indicate a general tendency for more chlorinated PCDD/Fs to have higher transfer factors in liver.

Outdoor pigs

Intakes of feed, soil and milk

The pigs were reared on fields largely devoid of vegetation, making it likely that the animals ingested soil whilst foraging for food. For most of the animals, the period selected represents the 28 days prior to slaughter and the collection of the relevant tissue sample(s). For two of the pigs, the period was taken as the full duration of the lives of the animals i.e. 25 days. 
Mean daily feed intakes were calculated from the feed consumption profile as described above for indoor pigs. The mean daily feed intakes for the two pigs slaughtered at 81 days was $0.90 \mathrm{~kg} \cdot \mathrm{d}^{-1}$ and for the two slaughtered at 142 days it was $2.12 \mathrm{~kg}^{-1}$. In the case of the pigs slaughtered at 25 days, these animals were only provided with feed for the last 5 days of their lives. Total consumption during this period was $1.0 \mathrm{~kg}$ which gave a mean daily intake of $0.04 \mathrm{~kg} . \mathrm{d}^{-1}$ when averaged over the 25 day period.

To allow comparisons with growing pigs, the daily feed consumption by the sow was calculated over the 28 day period immediately prior to the slaughter of the animal. Feed intake was derived from the consumption profile, and was calculated as $4.08 \mathrm{~kg} \cdot \mathrm{d}^{-1}$.

Several authors have attempted to estimate the amounts of soil ingested by pigs whilst foraging for food (see earlier). One method involves the use of an indicator such as titanium that is present in soil but is not taken up by plants. The concentration of the indicator in the faeces of the animal can then be used to estimate the rate of soil intake. Another approach is to calculate soil intakes as a \% of feed intake (Fries et al 1982; Fries 1996). For example, Fries et al (1982) reported a soil intake ranging from $1.2-5.7 \%$ of dry mass feed intake. On the basis of the percentages reported, together with the relatively dry conditions during the rearing period, a daily soil intake of $3.5 \%$ of feed intake was used as an estimate for the present study, which gave values

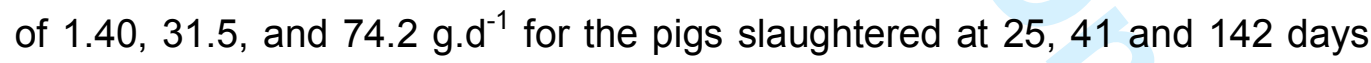
respectively and $143 \mathrm{~g} \cdot \mathrm{d}^{-1}$ for the sow.

The titanium method of measuring soil intakes was also used to provide useful supporting data to the calculations based on feed intake. Samples of faeces were therefore collected from the young pigs and analysed. Freshlyvoided faeces collected directly from the animal at various stages of the rearing process are ideally required if reliable results are to be achieved by this method (Fries et al 1982), but these were not possible to collect 
A third potential source of dietary PCB and PCDD/F intake into growing pigs is sow's milk. The mean daily volume of milk (8.3 litres $\left.\mathrm{d}^{-1}\right)$ produced by the sow over the period 2-27 September was estimated from the profile of milk production based on the data that were collected. As the litter consisted of 10

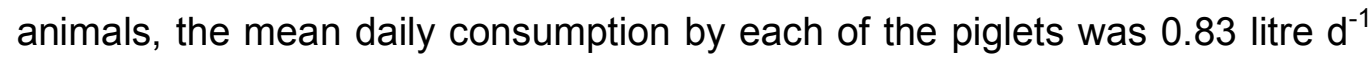
over the 25 day period. The young pigs slaughtered aged 81 and 142 days respectively, received no sow's milk during the corresponding consumption periods.

\section{Intake flux and BTFs}

Intake details were combined with data on concentrations of PCDD/F and PCB congeners to calculate BTFs for nine samples from the outdoor pig rearing programme. No sample of sow's milk was available for the outdoor pigs, so the value obtained from the indoor programme was substituted.

The BTFs were calculated using the same method as explained for indoor pigs and a complete set of the congener BTFs for the nine samples is given in Table 7. Summary results for the four selected congeners are presented in Table 8. This table shows a number of trends similar to those found for indoor pigs, including a tendency for the meat BTFs to decline in magnitude during the rearing programme and the very different results for liver compared to other samples. The BTFs again indicate a general trend for more chlorinated $\mathrm{PCDD} / \mathrm{Fs}$ to have much higher transfer factors in liver. Of course, as the animal grows there is a dilution effect of the contaminants that needs to be considered when drawing overall conclusions.

For all 39 congeners, the total input flux at 25 days was dominated by sows' milk, whilst in the later samples feed typically accounted for $88-93 \%$ and soil the remainder. As with the indoor pigs, the change from milk to feed is associated with a higher ranking in the meat BTFs for PCB 169, but it is difficult to attribute any obvious effect from the soil intake in outdoor pigs. Given the small proportion of total input from soil this is not surprising, but in market-ready animals soil typically accounted for around $50 \%$ of the input flux for several of the more chlorinated PCDD/Fs. This point highlights the 
contrasting PCDD/F and PCB profiles of commercial feed and soil, but overall the results indicated considerable consistency in the patterns of transfer and uptake between the two pig rearing programmes There are also some differences e.g. for outdoor pigs BTFs decrease with age for all congeners (Table 7) whereas for indoor pigs several congeners show an increase with age (Table 5). For outdoor pigs, BTFs for TCDD and 2,3,4,7- PeCDF increase whilst for indoor pigs a dip at day 90 was observed. Overall, BTFs for outdoor pigs were much higher.

Full details including congener specific results for all samples analysed are available in the contractors report (Foxall et al, 2004).

\section{Conclusions}

The analytical data obtained from the indoor and outdoor pig rearing programmes were generally in agreement with the results of previous studies and appear consistent with the PCDD/F and PCB levels to be expected from animals raised in rural background locations. The contribution of PCBs to the total TEQ values found also agrees with data previously reported. A slight decrease with age in total TEQ values in meat was evident in the indoor and outdoor pig rearing programme reported here, similar to that seen for lowland and highland sheep and for broiler chicken rearing programmes (Fernandes et al, 2011). Total TEQs in meat were found to be generally lower than those recorded in commercial feeds and there is consequently no evidence for a general trend in which pigs accumulate higher levels of PCDD/Fs and PCBs in meat through the ingestion of feed.

The total TEQs in pig liver were much higher than in meat and kidney samples from the same animals. Despite the animals being reared in rural background conditions, the PCDD/F TEQ values of all four liver samples exceeded the current EU maximum limits (6 $\mathrm{ng}$ PCDD/F-TEQ/kg fat) for liver and liver products. Liver samples were also characterised by much lower PCB contributions to the total TEQ than for the corresponding meat and kidney samples, and by a predominance of many of the hepta- and octasubstituted PCDD/Fs. 
At ages approaching market readiness, TEQ values in meat samples from outdoor pigs tended to be slightly higher than those from comparable ages in the indoor programme, suggesting that outdoor pigs accumulate these contaminants at a faster rate. It is possible that these differences might be attributable to additional exposure to PCB and PCDD/Fs from soil. It is also likely that the outdoor pigs had a higher body burden at birth since the outdoor sows had a higher contaminant concentration, although the impact of this would have been lost as the animals gained weight unless there was on-going exposure to higher concentrations.

Transfers of PCDD/Fs and PCBs from dietary sources to foodstuffs such as meat, liver and kidney were investigated through the calculation of biotransfer factors (BTFs). These coefficients were derived for each of 39 PCDD/F or PCB congeners. Interpretation of the findings focused particularly on trends in four selected congeners, namely 2,3,7,8-TCDD, 2,3,4,7,8-PeCDF, PCB 153 and PCB 169.

Particular dietary constituents also varied in their importance as contributors to the input flux of individual congeners. One example is that soil consistently accounted for at least $30 \%$ of input for many hexa- or more chlorinated PCDD/Fs, while rarely representing more than $10 \%$ of the total intake during a consumption period.

\section{Acknowledgement}

The authors would like to thank the referees for their comments on the manuscript. This work was funded by the UK Food Standards Agency. 


\section{References}

Agriculture Research Council (1967). The nutrient requirements of farm livestock. Technical review No. 3- pigs. Agricultural Research Council (Publishers).

Beck, H., Eckart, K., Marthar, W. and Wittkowski, R. (1989). PCDD and PCDF body burden from food intake in the Federal Republic of Germany. Chemosphere 18, 417-424.

Bernard, A., Broeckaert, F., De Poorter, G., De Cock, A., Hermans, C., Saegerman and Houins, G. (2002). The Belgian PCB/dioxin incident: analysis of the food chain contamination and health risk evaluation. Environ. Res. 88, $1-18$

Bluthgen, A., Heeschen, W. and Ruoff, U. (1995) Studies on the carry over of selected polychlorinated dibenzo-para-dioxins and -furans (PCDD/Fs) in the milk of lactating cows after oral supplementation. Milchwissenschaft 50 , 508-513.

Borchard, R. E., M. E. Welborn., Hansen, L. G., Link, R.P. and Teske, R. H. (1976). Apparent pharmacokinetics of PCB components in growing pigs and lambs when fed a ration containing Aroclor 1254. Archives of Environmental Contamination and Toxicology 4, 226-245.

British Society for Animal Science (2003). Nutrient requirement standards for pigs. BSAS, Scotland UK.

Chang, R., Hayward, D., Goldman, L., Harnly, M., Flattery, J. and Stephens, R. (1989) Foraging farm animals as biomonitors for dioxin contamination. Chemosphere 19, 481-486. 
Douben, P. E. T., Alcock, R. E. and Jones, K. C. (1997). Congener specific transfer of PCDD/Fs from air to cow's milk: an evaluation of current modelling approaches. Environ. Pollut. 95, 333-344.

Dunning, P. (2003). Easton Agricultural College - personal communication.

European Commission (2002) Council Directive 2002/70/EC of 26 July 2002 establishing requirements for the determination of levels of dioxins and dioxinlike PCBs in feedingstuffs. Official Journal of the European Communities, $L$ 209/15, 2002, p15-21

Fernandes, A., White, S., D'Silva, K. and Rose, M. Simultaneous determination of PCDDs, PCDFs, PCBs and PBDEs in food. Talanta 63 (5) $1147-1155$ (2004)

Fernandes, A., Mortimer, D., Rose, M. and Gem, M. (2010) Dioxins (PCDD/Fs) and PCBs in offal: Occurrence and dietary exposure. Chemosphere 81 536-540.

Fernandes, A., Foxall, C., Lovett, A, Rose, M., and Dowding, A... (2011) The assimilation of dioxins and $\mathrm{PCBs}$ in conventionally reared farm animals: Occurrence and biotransfer factors. Chemosphere, 83 815-822.

Focant, J. -F., Eppe, G., Pirard, C., Massart, A. -C., Andre, J.-E. and De Pauw, E. (2002). Levels and congener distributions of PCDDs, PCDFs and non- ortho PCBs in Belgian foodstuffs. Assessment of dietary intake. Chemosphere 48, 167-179. 
Chris Foxall, Andrew Lovett, Gisela Sunnenberg, Bob Anderson, Lisa Crook, Paul Dunning, Andrew Farley, Brian Fuller, David Morton, Chris Nix, Anna Shiels, Rachel Donkin, Alwyn Fernandes, Martin Rose, Shaun White. (2004) FINAL REPORT: TRANSFER AND UPTAKE OF ORGANIC CONTAMINANTS INTO MEAT AND EGGS OF CHICKENS, SHEEP AND PIGS. PROJECT CODE C01020. Available from Food Standards Agency.

Fries, G. F., Marrow, G. S. and Snow, P. A. (1982). Soil ingestion by swine as a route of contaminant exposure. Environ. Toxicol. Chem. 1, 201-204

Fries, G. F. (1996). Ingestion of sludge applied organic chemicals by animals. Sci. Total. Environ. 185, 93-108.

Furst, P., Furst, C. and Groebal, W. (1990). Levels of PCDDs and PCDFs in food-stuffs from the Federal Republic of Germany. Chemosphere 20, 787792.

Goldman, L.R., Hayward, D.G., Flattery, J., Harnley, M.E., Patterson, D.G., Needham, L.L., Siegel, D., Chang, R., Stephens, R.D. and Kizer, K.W. (1989) Serum adipose and autopsy tissue PCDD and PCDF levels in people eating dioxin contaminated beef and chicken eggs. Chemosphere 19, 841-848.

Hansen, L. G., Washko, P. W., Tuinistra, L. G., Dorn, S. B. and Hinesly, T. D. (1981). Polychlorinated biphenyl, pesticide and heavy metal residues in swine foraging on sewage sludge amended soils. J.Agric.Food.Chem 29, $1012-$ 1017.

Harrad, S. J. and Smith, D. J. T. (1997). Evaluation of a terrestrial food chain model for estimating foodstuff concentrations of PCDD/Fs. Chemosphere 34, 1723-1737.

Healey, W. B., Cutress, T. W. and Michie, C. (1967). Wear of sheep's teeth IV. Production of soil ingestion and tooth wear by supplementary feeding. New Zealand, J. Agric. Res. 10, 201-209. 
Healy W. B and Drew, K R (1970). Ingestion of soil by hoggets grazing swedes. New Zealand, J. Agric. Res. 13, 940-944.

Jacobs L, W.,Fries, G.F., Shull, L. R. and Sleight, S. D. (1981). Residual polybrominated biphenyl contamination of farms: Environmental repositories of residual contamination. Abstracts of the second annual meeting of the Society of Environmental Toxicology and Chemistry.

Liem, A. K. D. and Theelen, R.M.C. (1997). Dioxins: Chemical analysis, exposure and risk assessment. Thesis, National Institute of Public Health and the Environment, Bilthoven, The Netherlands. ISBN 90-393-2012-8.

Lorber, M., Saunders, P., Ferrario, J., Leese, W., Winters, D., Cleverly, D., Schaum, J., Deyrup, C., Ellis, R., Walcott, J., Dupuy, A., Byrne, C., McDaniel, D., (1997). A statistical survey of dioxin-like compounds in United States pork fat. Organohalogen Compounds 32, 238-244.

McLachlan, M.S. (1993) Mass balance of polychlorinated biphenyls and other organochlorine compounds in a lactating cow. J. Agric. Food Chem. 41, 474480 .

McLachlan, M. S. (1997). A simple model to predict accumulation of PCDD/Fs in an agricultural food chain. Chemosphere 34, 1263-1276.

National Institute of Public Health (2005) "Interlaboratory Comparison on dioxins in food - Second round of an International Study", Oslo, Norway, ISBN 82-7364-178-3

Rose, M., Mortimer, D., Gem, M., Petch, R., Fernandes, A. and Livesey, C. (2010) Considerations for the regulation of polychlorinated dibenzodioxins, furans (PCDD/Fs) and biphenyls (PCBs) in liver. Quality Assurance and Safety of Crops and Foods 2 (2) 72-77 
Rose, M., Harrison, N., Gem, M., Fernandes, A., White, S., Duff, M., Costley, C., Leon, I., Petch, R., Holland, J. and Chapman, A. Dioxins and polychlorinated biphenyls (PCDD/Fs and PCBs) in food from farms close to foot and mouth disease animal pyres. Journal of Environmental Monitoring 7 378-383 (2005)

Ryan, J. J., Lizotle, R., Sakuma, T. and Mori, B. (1985). Chlorinated dibenzopara-dioxins, chlorinated dibenzofurans and pentachlorophenol in Canadian chicken and pork samples. J. Agric. Food Chem. 33, 1021-1026.

Rychen, G., Laurent, C., Feidt, C., Grova, N., Lafargue, P. E., Hachimi, A. and Laurent, F. (2002). Milk-arterial plasma transfer of PCDDs and PCDFs in pigs. J. Agric. Food Chem. 50, 1695-1699.

Schuler, F., Schmid, P., and Schlatter.C. (1997) Transfer of airbourne polychlorinated dibenzo-p-dioxins and dibenzofurans into dairy milk. $J$. Agric.Food Chem. 45, 4162-4167.

Slob, W., Olling, M., Derks, H.J.G.M. and de Jong, A.P.J.M. (1995) Congener-Specific bioavailability of PCDD/F's and coplanar PCBs in cows. Chemosphere 31, 3827-3828.

Stevens, J.B. and Gerbec, E.N. (1998) Dioxin in the agricultural food chain. Risk Analysis 8, 329-335.

Thomas, G. O., Sweetman, A. J. and Jones, K. C. (1999). Input-output balance of polychlorinated biphenyls in a long-term study of lactating daily cows. Environ. Sci. Technol. 33, 104-112.

Whittemore, C. T. (2003). University of Edinburgh - personal communication.

Wittsiepe, J., Erlenkämper, B., Welge, P., Hack, A., and Wilhelm, M. (2004) Bioavailability of PCDD/F from contaminated soil in young Goettingen minipigs. Organohalogen Compounds 66, 2945-2951 
Wittsiepe, J., Erlenkämper, B., Welge, P., Hack, A., and Wilhelm, M. (2007) Bioavailability of PCDD/F from contaminated soil in young Goettingen minipigs. Chemosphere 67, S355-64 


\section{Figure 1: Outdoor pig programme - rearing and sampling schedules}
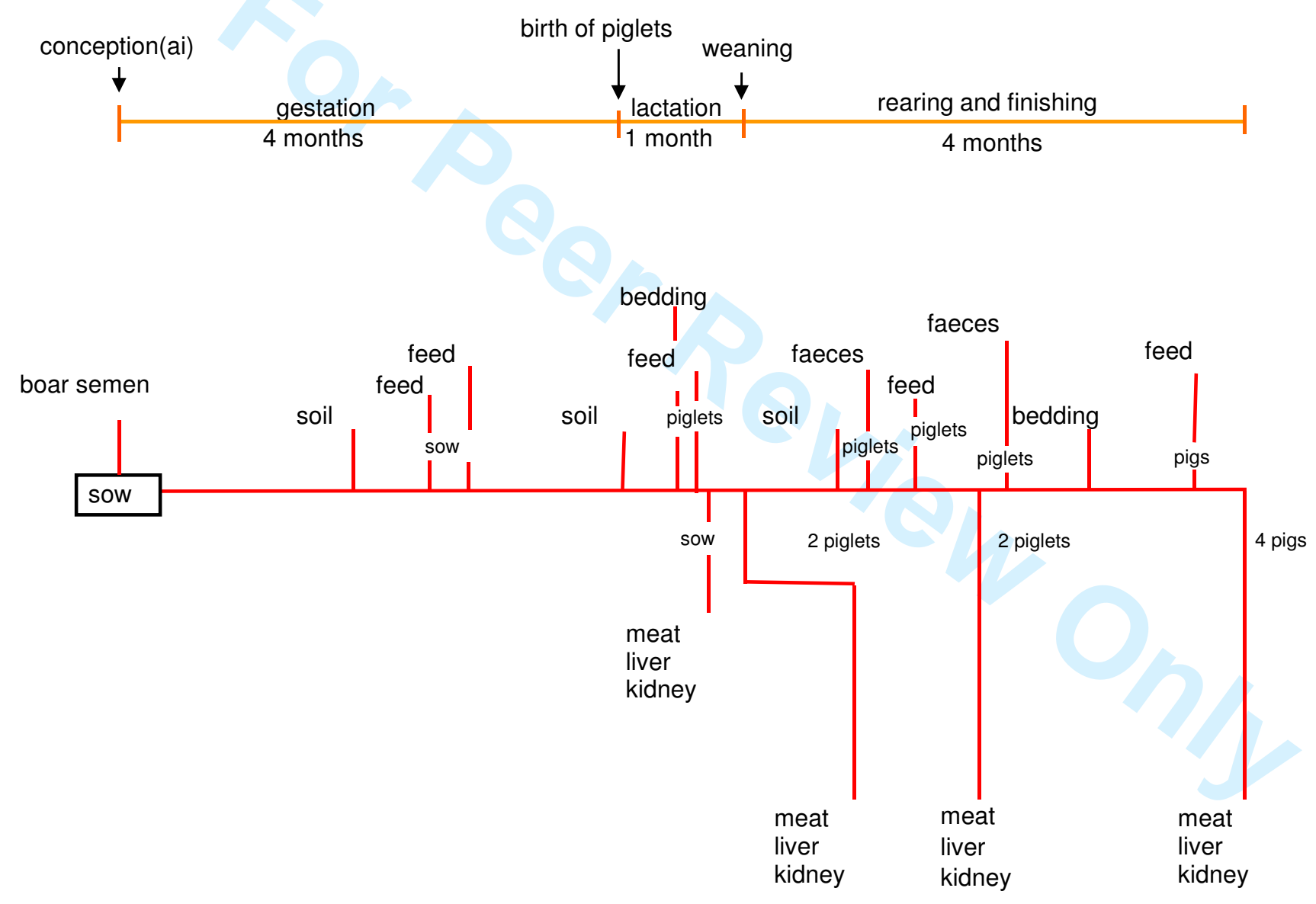

Notes

${ }^{1}$ Conception by artificial insemination

${ }^{2}$ Sow gave birth to 5 male and 5 female offspring 
Figure 2: Indoor pig programme - rearing and sampling schedules
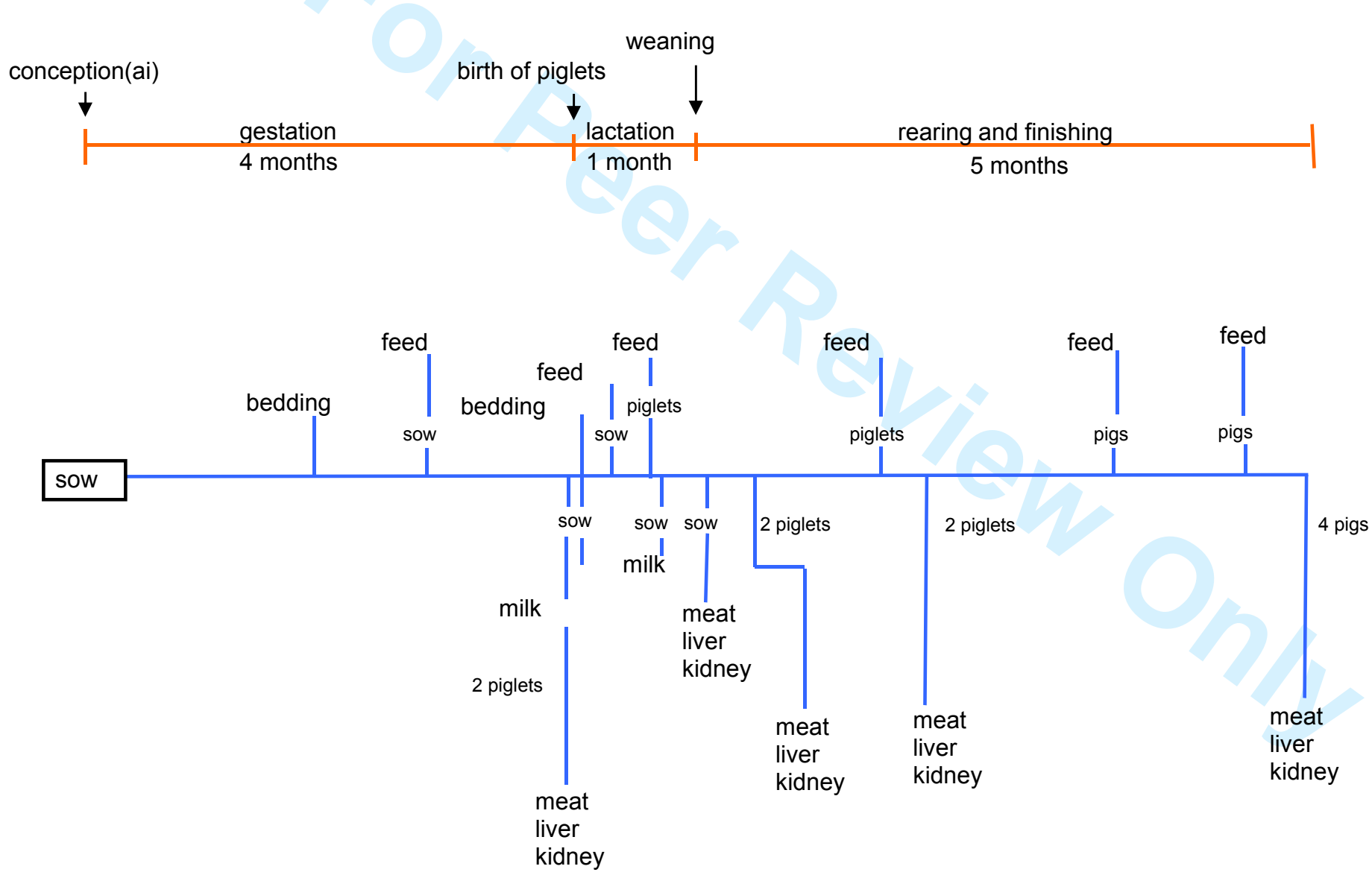

Notes

1 Conception by artificial insemination

2 Sow gave birth to 8 male and 2 female offspring 
Figure 3 : Outdoor pig programme - daily feed intake $\left(\mathrm{kgd}^{-1}\right)$ by sow

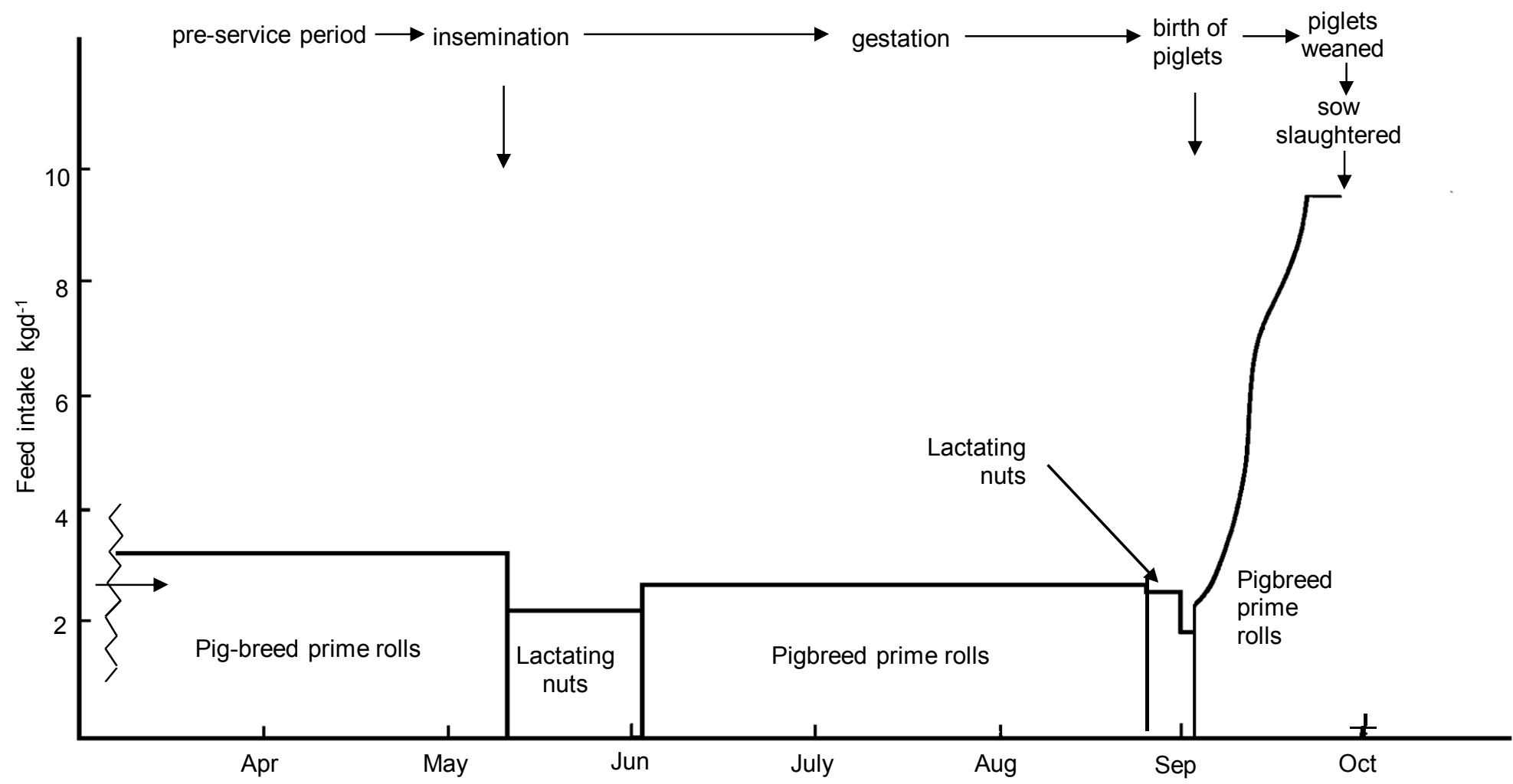


Figure 4: Outdoor pig programme - daily feed intake ( $\mathrm{kgd}^{-1}$ per animal) by growing pigs

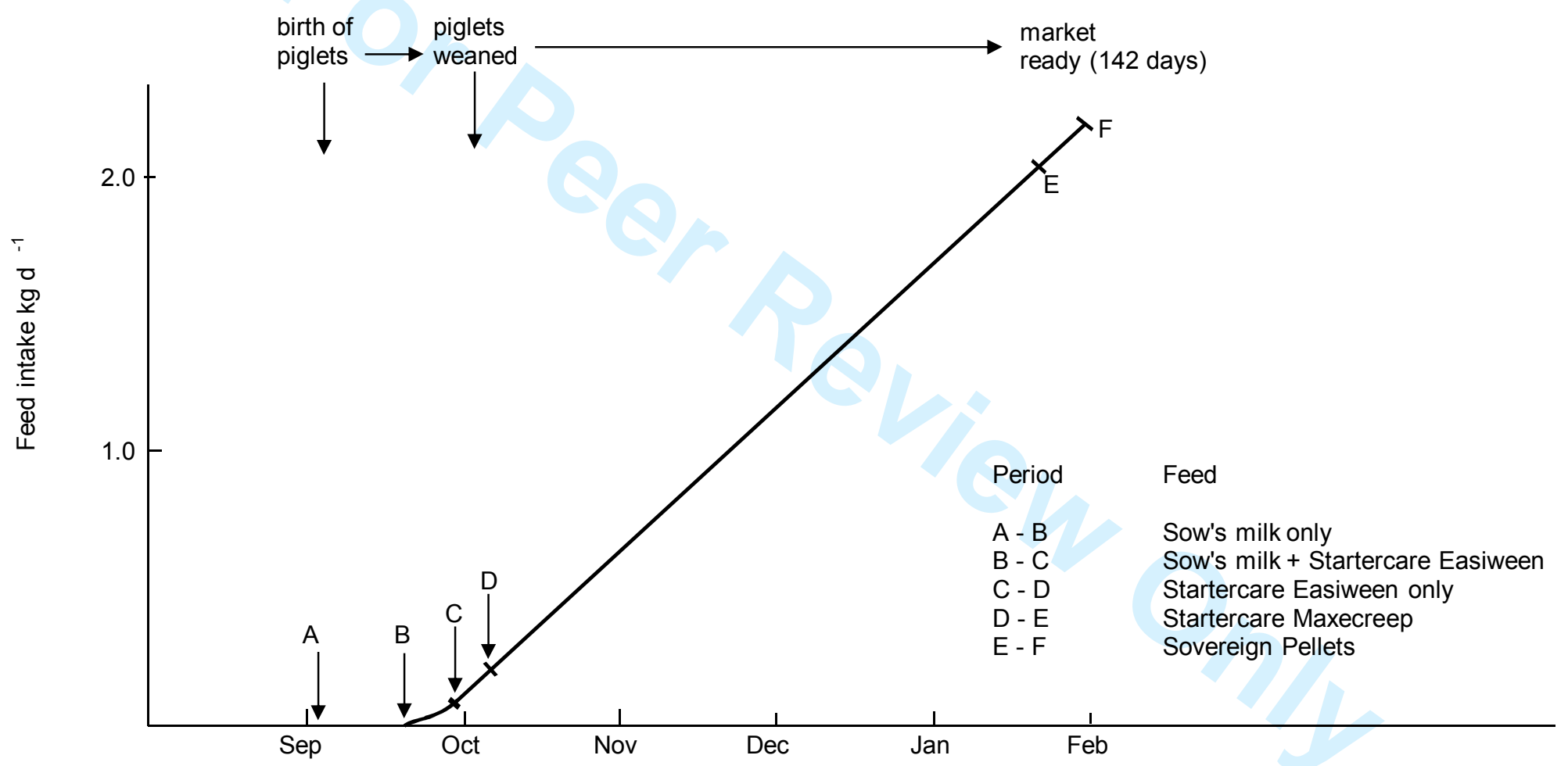

http://mc.manuscriptcentral.com/tfac Email: fac@tandf.co.uk 
Figure 5 : Indoor pig programme - daily feed intake $\left(\mathrm{kgd}^{-1}\right)$ by sow

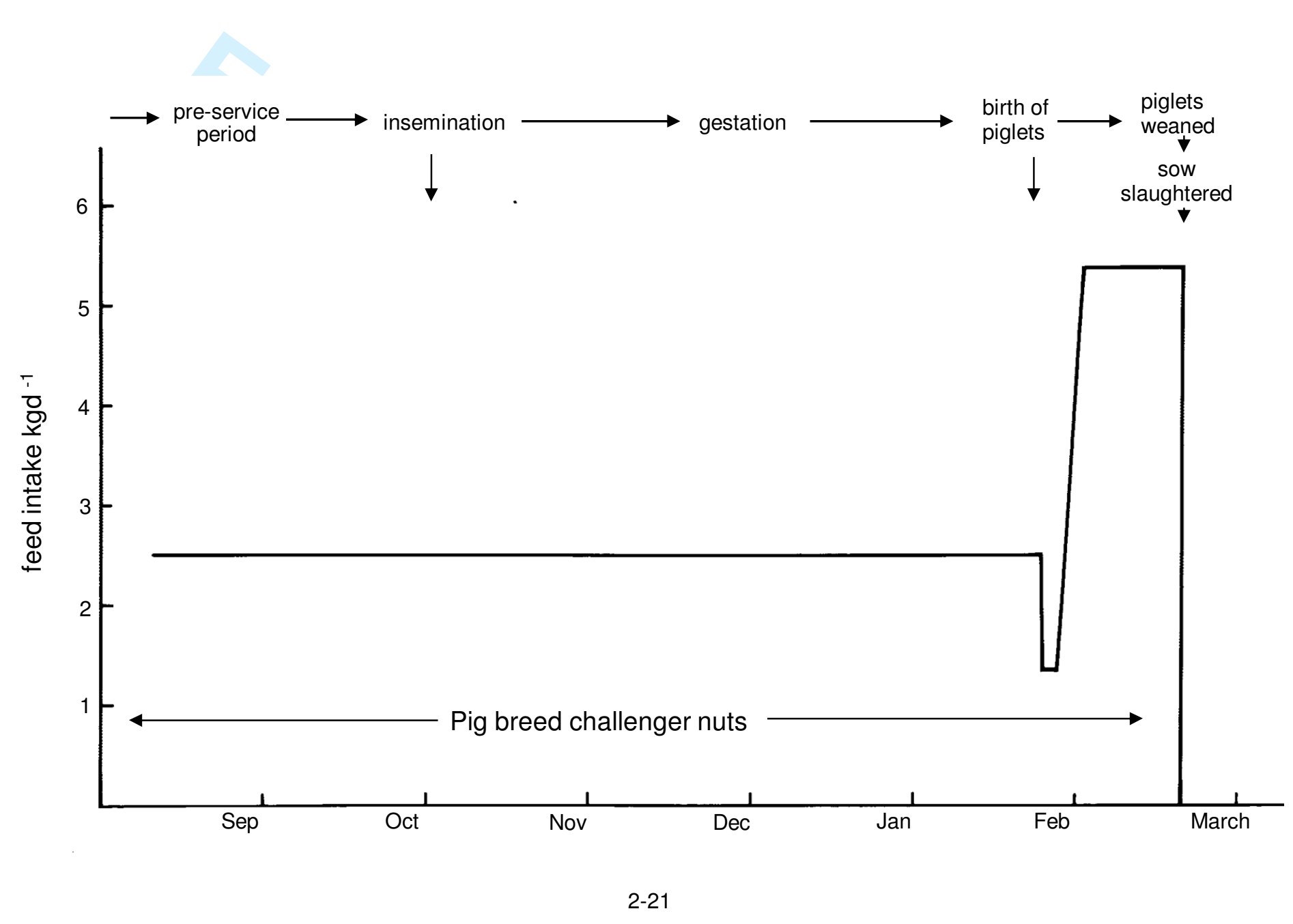

http://mc.manuscriptcentral.com/tfac Email: fac@tandf.co.uk 
Figure 6: Indoor pig programme - daily feed intake $\left(\mathrm{kgd}^{-1}\right.$ per animal) by growing pigs

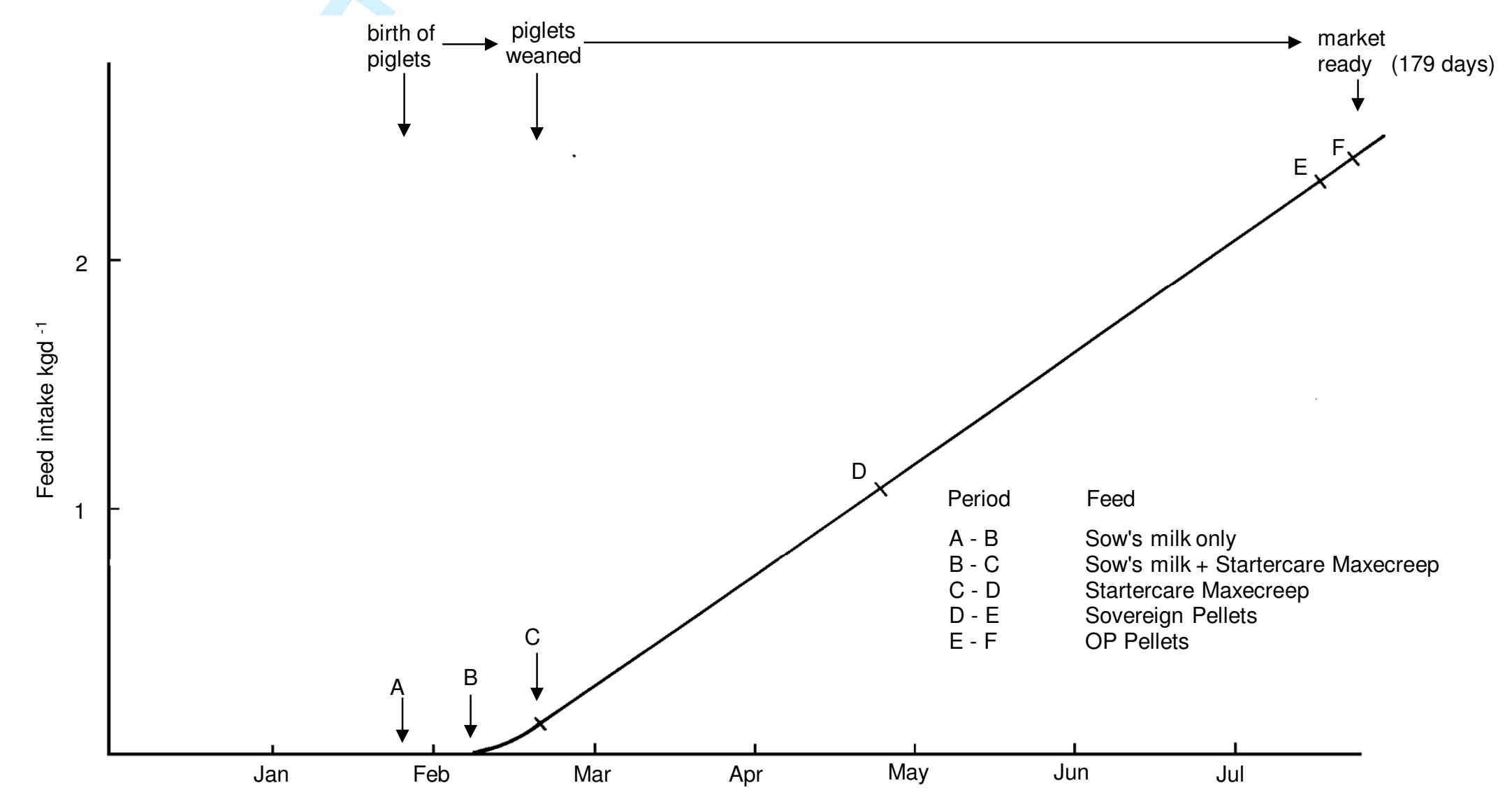

http://mc.manuscriptcentral.com/tfac Email: fac@tandf.co.uk 
Table 1: - details of routine veterinary inputs to sows

\begin{tabular}{|c|c|c|}
\hline Input & Dose & Notes \\
\hline \multicolumn{3}{|l|}{ Sow (outdoor) } \\
\hline Heptavac & $5 \mathrm{ml}$ & \\
\hline Heptavac & $5 \mathrm{ml}$ & $\begin{array}{l}\text { Vaccination against Clostridia } \\
\text { and tetanus }\end{array}$ \\
\hline \multicolumn{3}{|l|}{ Sow (indoor) } \\
\hline Illiren & $3 \mathrm{ml}$ & Used to induce farrowing \\
\hline Suraxyn Parvo & $2 \mathrm{ml}$ & Prevent Parvo virus infection \\
\hline Colisorb & $2 \mathrm{ml}$ & $\begin{array}{l}\text { Prevent erysipelas in sows and } \\
\text { piglets. } \\
\text { Protect piglets against neonatal } \\
\text { E.coli }\end{array}$ \\
\hline Heptavac & $2 \mathrm{ml}$ & $\begin{array}{l}\text { Vaccination against clostridia } \\
\text { and tetanus in piglets. }\end{array}$ \\
\hline Licel / Mange wash & $5 \mathrm{ml}$ & $\begin{array}{l}\text { External treatment just before } \\
\text { farrowing against greasy skin } \\
\text { syndrome. }\end{array}$ \\
\hline \multicolumn{3}{|l|}{ Piglets (indoor) } \\
\hline Iron solution & $20 \mathrm{ml}$ & Prevention of anaemia \\
\hline Dapmamox LA & $20 \mathrm{ml}$ & $\begin{array}{l}\text { Protect against infection of } \\
\text { joints following abrasion } \\
\text { injuries. }\end{array}$ \\
\hline
\end{tabular}

Note: In contrast to the young pigs reared indoors, the outdoor reared piglets received no veterinary inputs. 


\section{Table 7: Biotransfer Factors (BTFs) for Outdoor Pigs}

\begin{tabular}{|c|c|c|c|c|c|c|c|c|c|}
\hline & & & & & & & & & \\
\hline Sample Type & Meat & Meat & Meat & Meat & Meat & Meat & Liver & Kidney & Meat \\
\hline Age (Days) & 25 & 25 & 81 & 81 & 142 & 142 & 142 & 142 & Adult \\
\hline Input Flux (ng/day) & 243 & 243 & 376 & 376 & 1373 & 1373 & 1373 & 1373 & 1913 \\
\hline \multirow{2}{*}{ Fat Content (\%) } & 6.80 & 6.07 & 3.87 & 3.29 & 4.31 & 4.76 & 3.32 & 8.11 & 2.66 \\
\hline & & 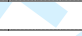 & & & & & & & \\
\hline \multicolumn{10}{|l|}{ day $/ \mathrm{kg}$ fat } \\
\hline 2,3,7,8-TCDD & 34.28 & 37.54 & 2.58 & 10.75 & 2.46 & 0.88 & 2.63 & 2.28 & 1.32 \\
\hline $1,2,3,7,8-\mathrm{PeCDD}$ & 40.07 & 46.75 & 4.25 & 8.50 & 1.71 & 0.49 & 13.81 & 1.59 & 0.92 \\
\hline $1,2,3,4,7,8-\mathrm{HxCDD}$ & 41.71 & 39.11 & 5.84 & 8.23 & 4.19 & 1.20 & 73.64 & 1.80 & 1.55 \\
\hline $1,2,3,6,7,8-\mathrm{HxCDD}$ & 19.81 & 19.81 & 5.73 & 6.26 & 4.33 & 1.06 & 46.02 & 1.69 & 1.53 \\
\hline $1,2,3,7,8,9-\mathrm{HxCDD}$ & 54.89 & 63.12 & 1.75 & 7.50 & 1.82 & 0.54 & 18.75 & 1.71 & 0.73 \\
\hline $1,2,3,4,6,7,8-\mathrm{HpCDD}$ & 16.02 & 12.69 & 3.07 & 2.39 & 2.67 & 0.85 & 107.87 & 1.17 & 0.74 \\
\hline OCDD & 6.15 & 5.80 & 1.38 & 1.15 & 1.40 & 0.61 & 100.03 & 0.77 & 0.57 \\
\hline $2,3,7,8-\mathrm{TCDF}$ & 12.77 & 15.09 & 1.26 & 5.95 & 1.14 & 0.38 & 1.77 & 1.07 & 0.52 \\
\hline $1,2,3,7,8-\mathrm{PeCDF}$ & 35.58 & 40.33 & 2.05 & 6.93 & 1.98 & 0.69 & 2.08 & 1.39 & 0.63 \\
\hline $2,3,4,7,8-\mathrm{PeCDF}$ & 52.34 & 41.51 & 5.80 & 7.97 & 3.55 & 0.95 & 154.05 & 1.47 & 1.56 \\
\hline $1,2,3,4,7,8-\mathrm{HxCDF}$ & 47.80 & 42.71 & 7.71 & 5.38 & 4.24 & 1.47 & 158.16 & 2.12 & 1.74 \\
\hline $1,2,3,6,7,8-\mathrm{HxCDF}$ & 34.68 & 28.65 & 5.15 & 5.72 & 3.60 & 0.93 & 152.80 & 1.54 & 1.13 \\
\hline $1,2,3,7,8,9-\mathrm{HxCDF}$ & 54.04 & 58.55 & 3.19 & 5.84 & 1.21 & 1.01 & 11.95 & 1.21 & 0.93 \\
\hline $2,3,4,6,7,8-\mathrm{HxCDF}$ & 28.03 & 22.78 & 3.73 & 5.60 & 2.10 & 0.54 & 140.73 & 1.01 & 0.76 \\
\hline $1,2,3,4,6,7,8-\mathrm{HpCDF}$ & 12.52 & 11.02 & 3.49 & 1.97 & 3.10 & 0.91 & 175.54 & 1.13 & 1.33 \\
\hline $1,2,3,4,7,8,9-\mathrm{HpCDF}$ & 36.96 & 42.65 & 2.23 & 10.78 & 2.42 & 0.76 & 91.51 & 2.27 & 0.41 \\
\hline OCDF & 27.17 & 30.73 & 0.66 & 2.36 & 0.59 & 0.25 & 27.56 & 0.33 & 0.19 \\
\hline PCB77 & 82.01 & 136.45 & 2.58 & 11.54 & 1.24 & 2.40 & 1.34 & 1.61 & 2.54 \\
\hline PCB81 & 60.06 & 95.44 & 2.89 & 9.59 & 1.78 & 2.40 & 3.57 & 1.17 & 2.58 \\
\hline PCB 126 & 28.38 & 42.57 & 7.42 & 19.58 & 2.75 & 2.87 & 23.95 & 2.57 & 1.52 \\
\hline PCB 169 & 19.96 & 24.14 & 21.95 & 17.10 & 7.40 & 3.49 & 13.94 & 1.35 & 6.88 \\
\hline PCB18 & 23.44 & 23.44 & 6.74 & 8.58 & 3.84 & 1.83 & 2.74 & 2.01 & 0.93 \\
\hline PCB28 & 63.18 & 48.82 & 5.82 & 7.41 & 8.23 & 2.40 & 2.57 & 1.89 & 2.42 \\
\hline PCB31 & 26.75 & 25.26 & 6.74 & 8.58 & 3.84 & 1.83 & 2.74 & 1.83 & 1.19 \\
\hline PCB52 & 30.61 & 32.88 & 8.87 & 8.44 & 3.32 & 2.04 & 4.21 & 1.79 & 1.49 \\
\hline PCB99 & 31.67 & 32.76 & 28.19 & 20.84 & 8.47 & 3.36 & 6.87 & 3.36 & 4.90 \\
\hline PCB101 & 77.93 & 105.70 & 14.11 & 10.58 & 2.75 & 1.17 & 1.83 & 1.33 & 5.13 \\
\hline PCB 105 & 21.52 & 30.12 & 6.74 & 8.58 & 3.84 & 1.83 & 2.74 & 1.83 & 1.74 \\
\hline PCB114 & 23.93 & 23.93 & 6.74 & 8.58 & 3.84 & 1.83 & 2.74 & 1.83 & 1.34 \\
\hline PCB118 & 35.24 & 52.44 & 17.89 & 13.41 & 3.68 & 1.84 & 2.65 & 2.07 & 4.12 \\
\hline PCB 123 & 23.93 & 36.70 & 6.74 & 8.58 & 3.84 & 1.83 & 2.74 & 3.84 & 2.41 \\
\hline PCB 128 & 22.81 & 31.94 & 8.58 & 8.58 & 3.84 & 1.83 & 2.74 & 1.83 & 1.61 \\
\hline PCB138 & 50.18 & 110.43 & 28.51 & 20.67 & 5.68 & 3.36 & 6.84 & 3.42 & 15.40 \\
\hline PCB153 & 67.81 & 165.36 & 29.18 & 23.01 & 5.55 & 3.60 & 5.26 & 3.43 & 24.24 \\
\hline PCB156 & 23.93 & 23.93 & 6.74 & 8.58 & 3.84 & 1.83 & 2.74 & 1.83 & 1.34 \\
\hline PCB157 & 23.93 & 23.93 & 6.74 & 8.58 & 3.84 & 1.83 & 2.74 & 1.83 & 1.34 \\
\hline PCB167 & 23.93 & 33.50 & 6.74 & 8.58 & 3.84 & 1.83 & 2.74 & 1.83 & 1.61 \\
\hline PCB 180 & 52.32 & 197.03 & 21.83 & 18.29 & 5.72 & 3.03 & 4.38 & 2.86 & 21.99 \\
\hline PCB189 & 23.93 & 23.93 & 6.74 & 8.58 & 3.84 & 1.83 & 2.74 & 1.83 & 1.34 \\
\hline
\end{tabular}


Table 8: Biotransfer factors (BTFs) for selected PCDD/F and PCB congeners in the outdoor pig rearing programme

\begin{tabular}{|c|c|c|c|c|c|c|c|c|c|c|c|c|}
\hline \multirow{2}{*}{$\begin{array}{c}\text { Sample Type } \\
\text { Day of Sample Collection } \\
\text { Congener }\end{array}$} & \multicolumn{2}{|c|}{$\begin{array}{l}\text { Meat } \\
25 \\
\end{array}$} & \multicolumn{2}{|c|}{$\begin{array}{c}\text { Meat } \\
81\end{array}$} & \multicolumn{2}{|c|}{$\begin{array}{c}\text { Meat } \\
142 \\
\end{array}$} & \multicolumn{2}{|c|}{$\begin{array}{l}\text { Liver } \\
142 \\
\end{array}$} & \multicolumn{2}{|c|}{$\begin{array}{c}\text { Kidney } \\
142 \\
\end{array}$} & \multicolumn{2}{|c|}{$\begin{array}{c}\text { Sow Meat } \\
\text { Adult }\end{array}$} \\
\hline & $\mathrm{BTF}^{2}$ & Rank $^{3}$ & $\mathrm{BTF}^{2}$ & Rank $^{3}$ & BTF $^{2}$ & Rank $^{3}$ & BTF $^{2}$ & $\operatorname{Rank}^{3}$ & BTF $^{2}$ & Rank $^{3}$ & BTF $^{2}$ & Rank $^{3}$ \\
\hline 2,3,7,8-TCDD & 35.91 & 17 & 6.67 & 23 & 1.67 & 30 & 2.63 & 34 & 2.28 & 7 & 1.32 & 26 \\
\hline $2,3,4,7,8-\mathrm{PeCDF}$ & 46.93 & 10 & 6.89 & 22 & 2.25 & 24 & 154.05 & 3 & 1.47 & 28 & 1.56 & 16 \\
\hline PCB 169 & 22.05 & 34 & 19.52 & 5 & 5.44 & 2 & 13.94 & 14 & 1.35 & 30 & 6.88 & 4 \\
\hline PCB 153 & 116.58 & 2 & 26.10 & 1 & 4.57 & 4 & 5.26 & 19 & 3.43 & 2 & 24.24 & 1 \\
\hline $\begin{array}{l}\text { Average for } 39 \mathrm{PCDD} / \mathrm{F} \\
\text { or PCB Congeners }\end{array}$ & 41.95 & & 8.82 & & 2.58 & & 35.48 & & 1.84 & & 3.20 & \\
\hline & & & & & & & & & & & & \\
\hline
\end{tabular}


Table 2: nature and levels of feed consumption by growing pigs (Sept 2001 - Jan 2002)

\begin{tabular}{|c|c|c|c|c|c|}
\hline $\begin{array}{l}\text { Age at slaughter } \\
\text { (days) }\end{array}$ & $\begin{array}{l}\text { Type of feed } \\
\text { consumed }\end{array}$ & $\begin{array}{l}\text { Duration of } \\
\text { consumption } \\
\text { period(days) }\end{array}$ & $\begin{array}{l}\text { Mean feed } \\
\text { intake }^{1} \\
\left(\mathrm{kgd}^{-1}\right)\end{array}$ & $\begin{array}{l}\text { Total intake of } \\
\text { each feed }(\mathrm{kg})\end{array}$ & $\begin{array}{l}\text { Cumulative feed } \\
\text { intake }^{2}(\mathrm{~kg})\end{array}$ \\
\hline 25 & $\begin{array}{l}\text { Startercare } \\
\text { Easiween }\end{array}$ & 5 & 0.2 & 1.0 & 1.0 \\
\hline 81 & $\begin{array}{l}\text { Startercare } \\
\text { Easiween } \\
\text { Startercare } \\
\text { Maxecreep }\end{array}$ & $\begin{array}{l}13 \\
48\end{array}$ & $\begin{array}{l}0.2 \\
0.8\end{array}$ & $\begin{array}{l}2.6 \\
39.4\end{array}$ & 42.0 \\
\hline 142 & $\begin{array}{l}\text { Startercare } \\
\text { Easiween } \\
\text { Startercare } \\
\text { Maxecreep } \\
\text { Sovereign } \\
\text { Pellets }\end{array}$ & $\begin{array}{l}13 \\
94 \\
13\end{array}$ & $\begin{array}{l}0.2 \\
1.3 \\
2.3\end{array}$ & $\begin{array}{l}2.6 \\
118 \\
29.9\end{array}$ & 151 \\
\hline
\end{tabular}

\section{Indoor pig programme -}

\begin{tabular}{|c|c|c|c|c|c|}
\hline 0.0 & - & - & - & - & - \\
\hline 27 & $\begin{array}{l}\text { Startercare } \\
\text { Maxecreep }\end{array}$ & 10 & 0.1 & 1.0 & 1.0 \\
\hline 90 & $\begin{array}{l}\text { Startercare } \\
\text { Maxecreep }\end{array}$ & 73 & 0.5 & 36.5 & 36.5 \\
\hline 179 & $\begin{array}{l}\text { Startercare } \\
\text { Maxecreep } \\
\text { Sovereign } \\
\text { Pellets } \\
\text { OP Pellets }\end{array}$ & $\begin{array}{l}73 \\
84 \\
5\end{array}$ & $\begin{array}{l}0.5 \\
1.7 \\
2.4\end{array}$ & $\begin{array}{l}36.5 \\
143 \\
12.0\end{array}$ & 192 \\
\hline
\end{tabular}

Notes

${ }^{1}$ Value quoted is mean daily intake over consumption period indicated

${ }^{2}$ Figures are calculated for period from birth to day of slaughter 
Table 3: (a) Summary of PCDD/F and PCB concentrations (upper bound TEQs) for samples in the indoor pig rearing programme

\begin{tabular}{|c|c|c|c|c|}
\hline Sample Type & $\begin{array}{c}\text { Day of Sample } \\
\text { Collection }^{1}\end{array}$ & $\begin{array}{l}\text { Total } \\
\text { TEQ }^{2} \\
\end{array}$ & $\begin{array}{l}\text { PCB Contribution } \\
\text { to Total TEQ }(\%)\end{array}$ & $\begin{array}{l}\text { Congeners } \\
\text { Below LOD }\end{array}$ \\
\hline Indoor Bedding* & & 0.24 & 54.17 & 13 \\
\hline Sow Milk & 0 & 0.53 & 47.17 & 18 \\
\hline Sow Milk & 0 & 0.64 & 45.31 & 18 \\
\hline Sow Feed & & 3.67 & 45.78 & 25 \\
\hline Rearing Feed & & 5.20 & 45.00 & 33 \\
\hline Rearing Feed & & 3.38 & 46.15 & 30 \\
\hline Meat & 0 & 2.01 & 60.20 & 21 \\
\hline Meat & 27 & 1.00 & 79.00 & 10 \\
\hline Meat & 90 & 0.68 & 39.71 & 18 \\
\hline Meat & 90 & 0.92 & 39.13 & 18 \\
\hline Meat & 179 & 0.56 & 48.21 & 18 \\
\hline Meat & 179 & 0.72 & 43.06 & 21 \\
\hline Liver & 179 & 8.90 & 18.43 & 14 \\
\hline Kidney & 179 & 0.89 & 57.30 & 28 \\
\hline Sow Meat & Adult & 0.50 & 74.00 & 9 \\
\hline
\end{tabular}

Notes

*Composite of several samples.

${ }^{1}$ Day of sample collection during the rearing programme (i.e. $0=$ day of birth for piglets). ${ }^{2}$ TEQs are on a ng TEQ/kg fat basis for all samples except bedding (whole weight).

${ }^{3}$ Number of congeners below LOD out of the 39 PCDD/F and PCB congeners analysed. 
Table 3: (b) Summary of PCDD/F and PCB concentrations (upper bound TEQs) for samples in the outdoor pig rearing programme

\begin{tabular}{lcccc}
\hline Sample Type & $\begin{array}{c}\text { Day of Sample } \\
\text { Collection }\end{array}$ & $\begin{array}{c}\text { Total } \\
\text { TEQ }^{2}\end{array}$ & $\begin{array}{c}\text { PCB Contribution } \\
\text { to Total TEQ }(\%)\end{array}$ & $\begin{array}{c}\text { Congeners } \\
\text { Below LOD }\end{array}$ \\
\hline Soil & & & & 13 \\
Soil $^{*}$ & & 1.74 & 10.92 & 12 \\
Sow Feed & 1.94 & 13.92 & 23 \\
Sow Feed & & & 39.35 & 22 \\
Rearing Feed & & 1.55 & 41.56 & 15 \\
Rearing Feed & & 3.08 & 57.34 & 25 \\
Rearing Feed & & 3.54 & 40.11 & 19 \\
Meat & & 1.77 & 50.79 & 17 \\
Meat & & 4.41 & 37.90 & 14 \\
Meat & 25 & 1.24 & 42.96 & 22 \\
Meat & 25 & 1.35 & 44.58 & 17 \\
Meat & 81 & 0.83 & 40.54 & 16 \\
Meat & 81 & 1.48 & 43.80 & 20 \\
Liver & 142 & 1.37 & 62.90 & 12 \\
Kidney & 142 & 0.62 & 8.96 & 13 \\
Sow Meat & 142 & 20.65 & 43.68 & \\
\hline
\end{tabular}

Notes

${ }^{*}$ Composite of several samples.

${ }^{1}$ Day of sample collection during the rearing programme (i.e. $0=$ day of birth for piglets). ${ }^{2}$ TEQs are on a ng TEQ/kg fat basis for all samples except soil (whole weight).

${ }^{3}$ Number of congeners below LOD out of the 39 PCDD/F and PCB congeners analysed. 
Notes

${ }^{1}$ Total concentrations of dioxins and PCBs may not equal the sum of individual dioxins and PCBs due to rounding.

${ }^{2}$ Nationally representative composite samples of pork fat from animals collected from slaughterhouses across the country. Values $\angle \mathrm{LOD}=\mathrm{LOD}$.

${ }^{3}$ Sub-cutaneous belly fat samples from market-ready animals randomly selected from slaughterhouses across the country. Values $<\mathrm{LOD}=1 / 2 \mathrm{LOD}$.

${ }^{4}$ Pooled sample from various supermarkets. Values $<L O D=1 / 2 L O D$.

${ }^{5}$ Retail samples collected from four provinces of Catalonia. Values <LOD=LOD.

${ }^{6}$ Tenderloin samples from slaughterhouses. Values $\angle \mathrm{LOD}=0$.

${ }^{7}$ Retail samples collected from four provinces of Catalonia. Values <LOD=LOD.

${ }^{8}$ Samples collected from slaughterhouses or purchased in local supermarkets. Values $<L O D=0$. 
${ }^{1}$ Total concentrations of dioxins and PCBs may not equal the sum of the individual dioxins and PCBs due to rounding.

${ }^{2}$ Nationally representative composite samples of liver from animals collected from slaughterhouses across the country. Values $\angle \mathrm{LOD}=\mathrm{LOD}$.

${ }^{3}$ Material analysed was composite of retail offal samples from 24 locations across the UK collected as part of the 1992 Total Diet Study. Figures quoted are derived from values given in FSIS No. 105, reexpressed as WHO-TEQs. Values $\angle \mathrm{LOD}=\mathrm{LOD}$.

${ }^{4}$ Material analysed was composite of retail offal samples from 24 locations across the UK collected as

part of the 1997 Total Diet Study. Values <LOD=LOD.

\begin{tabular}{|c|c|c|c|c|c|c|c|}
\hline $\begin{array}{l}\text { PCDD/F } \\
\text { TEQ }\end{array}$ & $\begin{array}{l}\text { PCB TEQ } \\
\text { non-ortho } \\
\text { + ortho }\end{array}$ & $\begin{array}{l}\text { Total } \\
\text { TEQ }^{1}\end{array}$ & $\begin{array}{l}\text { \% PCB TEQ } \\
\text { contribution } \\
\text { to total TEQ }\end{array}$ & $\begin{array}{l}\text { Origin of } \\
\text { samples }\end{array}$ & $\begin{array}{l}\text { Number } \\
\text { of } \\
\text { samples }\end{array}$ & $\begin{array}{l}\text { Sampling } \\
\text { date }\end{array}$ & Reference \\
\hline \multicolumn{8}{|l|}{ LIVER } \\
\hline 15.0 & 2.0 & 17.0 & 12 & Netherlands & 2 & 1990 & $\begin{array}{l}\text { Liem and Theelen } \\
(1997)^{2}\end{array}$ \\
\hline 10.3 & 2.9 & 13.2 & 22 & UK & 1 & 1992 & $\operatorname{MAFF}(1997)^{3}$ \\
\hline 6.3 & 2.5 & 8.8 & 28 & UK & 1 & 1997 & FSA $(2000)^{4^{\prime}}$ \\
\hline \multicolumn{8}{|c|}{ Present study } \\
\hline 18.8 & 1.8 & 20.6 & 9.0 & UK & 1 & 2002 & $\begin{array}{l}\text { Market-ready outdoor } \\
\text { pig }\end{array}$ \\
\hline 7.3 & 1.6 & 8.9 & 18 & UK & 1 & 2002 & $\begin{array}{l}\text { Market-ready indoor } \\
\text { pig }\end{array}$ \\
\hline \multicolumn{8}{|c|}{ KIDNEY - present study } \\
\hline 0.49 & 0.38 & 0.87 & 44 & UK & 1 & 2002 & $\begin{array}{l}\text { Market-ready outdoor } \\
\text { pig }\end{array}$ \\
\hline 0.38 & 0.51 & 0.89 & 57 & UK & 1 & 2002 & $\begin{array}{l}\text { Market-ready indoor } \\
\text { pig }\end{array}$ \\
\hline
\end{tabular}

Notes 
Table 4: Example of BTF calculation for indoor pig meat sample

\begin{tabular}{|c|c|c|c|c|c|c|c|c|c|}
\hline $\begin{array}{c}\mathrm{PCDD} / \mathrm{F} \text { and } \mathrm{PCB} \\
\text { Congeners }\end{array}$ & $\begin{array}{c}\text { Meat } \\
\mathrm{ng} / \mathrm{kg} \text { fat }\end{array}$ & $\begin{array}{c}\text { Feed } \\
\mathrm{ng} / \mathrm{kg} \text { whole }\end{array}$ & $\begin{array}{c}\text { Daily Intake } \\
\mathrm{kg} \mathrm{d}^{-1}\end{array}$ & $\begin{array}{l}\text { Input Flux } \\
\text { ng d }^{-1}\end{array}$ & $\begin{array}{c}\text { Milk } \\
\mathrm{ng} / \mathrm{kg} \text { whole }\end{array}$ & $\begin{array}{c}\text { Daily Intake } \\
{\text { litres } d^{-1}}^{-1}\end{array}$ & $\begin{array}{l}\text { Input Flux } \\
\text { ng d }^{-1}\end{array}$ & $\begin{array}{c}\text { Sum Input Flux } \\
\mathrm{ng} \mathrm{d}^{-1}\end{array}$ & BTF \\
\hline 2,3,7,8-TCDD & 0.05 & 0.02508 & 0.04 & 0.0010032 & 0.006116 & 0.82 & 0.00501512 & 0.00601832 & 8.31 \\
\hline 1,2,3,7,8-PeCDD & 0.05 & 0.03531 & 0.04 & 0.0014124 & 0.003892 & 0.82 & 0.00319144 & 0.00460384 & 10.86 \\
\hline $1,2,3,4,7,8-\mathrm{HxCDD}$ & 0.06 & 0.01980 & 0.04 & 0.0007920 & 0.007228 & 0.82 & 0.00592696 & 0.00671896 & 8.93 \\
\hline $1,2,3,6,7,8-\mathrm{HxCDD}$ & 0.11 & 0.02376 & 0.04 & 0.0009504 & 0.015568 & 0.82 & 0.01276576 & 0.01371616 & 8.02 \\
\hline $1,2,3,7,8,9-\mathrm{HxCDD}$ & 0.05 & 0.02112 & 0.04 & 0.0008448 & 0.002224 & 0.82 & 0.00182368 & 0.00266848 & 18.74 \\
\hline $1,2,3,4,6,7,8-\mathrm{HpCDD}$ & 0.82 & 0.13398 & 0.04 & 0.0053592 & 0.121208 & 0.82 & 0.09939056 & 0.10474976 & 7.83 \\
\hline OCDD & 2.91 & 1.47807 & 0.04 & 0.0591228 & 1.013032 & 0.82 & 0.83068624 & 0.88980904 & 3.27 \\
\hline 2,3,7,8-TCDF & 0.13 & 0.01716 & 0.04 & 0.0006864 & 0.003336 & 0.82 & 0.00273552 & 0.00342192 & 37.99 \\
\hline $1,2,3,7,8-\mathrm{PeCDF}$ & 0.05 & 0.01452 & 0.04 & 0.0005808 & 0.002780 & 0.82 & 0.00227960 & 0.0028604 & 17.48 \\
\hline 2,3,4,7,8-PeCDF & 0.06 & 0.02772 & 0.04 & 0.0011088 & 0.003892 & 0.82 & 0.00319144 & 0.00430024 & 13.95 \\
\hline $1,2,3,4,7,8-\mathrm{HxCDF}$ & 0.11 & 0.02112 & 0.04 & 0.0008448 & 0.009452 & 0.82 & 0.00775064 & 0.00859544 & 12.80 \\
\hline $1,2,3,6,7,8-\mathrm{HxCDF}$ & 0.05 & 0.02772 & 0.04 & 0.0011088 & 0.006116 & 0.82 & 0.00501512 & 0.00612392 & 8.16 \\
\hline $1,2,3,7,8,9-\mathrm{H} x \mathrm{CDF}$ & 0.05 & 0.01848 & 0.04 & 0.0007392 & 0.001668 & 0.82 & 0.00136776 & 0.00210696 & 23.73 \\
\hline $2,3,4,6,7,8-\mathrm{HxCDF}$ & 0.05 & 0.02244 & 0.04 & 0.0008976 & 0.004448 & 0.82 & 0.00364736 & 0.00454496 & 11.00 \\
\hline $1,2,3,4,6,7,8-\mathrm{HpCDF}$ & 0.44 & 0.04587 & 0.04 & 0.0018348 & 0.112312 & 0.82 & 0.09209584 & 0.09393064 & 4.68 \\
\hline $1,2,3,4,7,8,9-\mathrm{HpCDF}$ & 0.04 & 0.01716 & 0.04 & 0.0006864 & 0.002780 & 0.82 & 0.00227960 & 0.002966 & 13.49 \\
\hline OCDF & 0.13 & 0.09042 & 0.04 & 0.0036168 & 0.018348 & 0.82 & 0.01504536 & 0.01866216 & 6.97 \\
\hline PCB 77 & 21.05 & 1.03422 & 0.04 & 0.0413688 & 0.138444 & 0.82 & 0.11352408 & 0.15489288 & 135.90 \\
\hline PCB 81 & 1 & 0.06369 & 0.04 & 0.0025476 & 0.010564 & 0.82 & 0.00866248 & 0.01121008 & 89.21 \\
\hline PCB 126 & 1.99 & 0.13926 & 0.04 & 0.0055704 & 0.027244 & 0.82 & 0.02234008 & 0.02791048 & 71.30 \\
\hline PCB 169 & 0.66 & 0.02376 & 0.04 & 0.0009504 & 0.043368 & 0.82 & 0.03556176 & 0.03651216 & 18.08 \\
\hline PCB 18 & 100 & 33 & 0.04 & 1.32 & 6.672 & 0.82 & 5.47104 & 6.79104 & 14.73 \\
\hline PCB 28 & 190 & 33 & 0.04 & 1.32 & 6.672 & 0.82 & 5.47104 & 6.79104 & 27.98 \\
\hline PCB 31 & 120 & 33 & 0.04 & 1.32 & 6.672 & 0.82 & 5.47104 & 6.79104 & 17.67 \\
\hline PCB 52 & 230 & 33 & 0.04 & 1.32 & 6.672 & 0.82 & 5.47104 & 6.79104 & 33.87 \\
\hline PCB 99 & 540 & 33 & 0.04 & 1.32 & 18.348 & 0.82 & 15.04536 & 16.36536 & 33.00 \\
\hline PCB 101 & 1170 & 33 & 0.04 & 1.32 & 7.228 & 0.82 & 5.92696 & 7.24696 & 161.45 \\
\hline PCB 105 & 160 & 33 & 0.04 & 1.32 & 6.672 & 0.82 & 5.47104 & 6.79104 & 23.56 \\
\hline PCB 114 & 100 & 33 & 0.04 & 1.32 & 6.672 & 0.82 & 5.47104 & 6.79104 & 14.73 \\
\hline PCB 118 & 520 & 33 & 0.04 & 1.32 & 8.896 & 0.82 & 7.29472 & 8.61472 & 60.36 \\
\hline PCB 123 & 400 & 33 & 0.04 & 1.32 & 6.672 & 0.82 & 5.47104 & 6.79104 & 58.90 \\
\hline PCB 128 & 230 & 33 & 0.04 & 1.32 & 6.672 & 0.82 & 5.47104 & 6.79104 & 33.87 \\
\hline PCB 138 & 9540 & 33 & 0.04 & 1.32 & 46.148 & 0.82 & 37.84136 & 39.16136 & 243.61 \\
\hline PCB 153 & 14730 & 33 & 0.04 & 1.32 & 53.932 & 0.82 & 44.22424 & 45.54424 & 323.42 \\
\hline PCB 156 & 170 & 33 & 0.04 & 1.32 & 6.672 & 0.82 & 5.47104 & 6.79104 & 25.03 \\
\hline PCB 157 & 650 & 33 & 0.04 & 1.32 & 6.672 & 0.82 & 5.47104 & 6.79104 & 95.71 \\
\hline PCB 167 & 100 & 33 & 0.04 & 1.32 & 6.672 & 0.82 & 5.47104 & 6.79104 & 14.73 \\
\hline PCB 180 & 29560 & 33 & 0.04 & 1.32 & 18.348 & 0.82 & 15.04536 & 16.36536 & 1806.25 \\
\hline PCB 189 & 100 & 33 & 0.04 & 1.32 & 6.672 & 0.82 & 5.47104 & 6.79104 & 14.73 \\
\hline
\end{tabular}




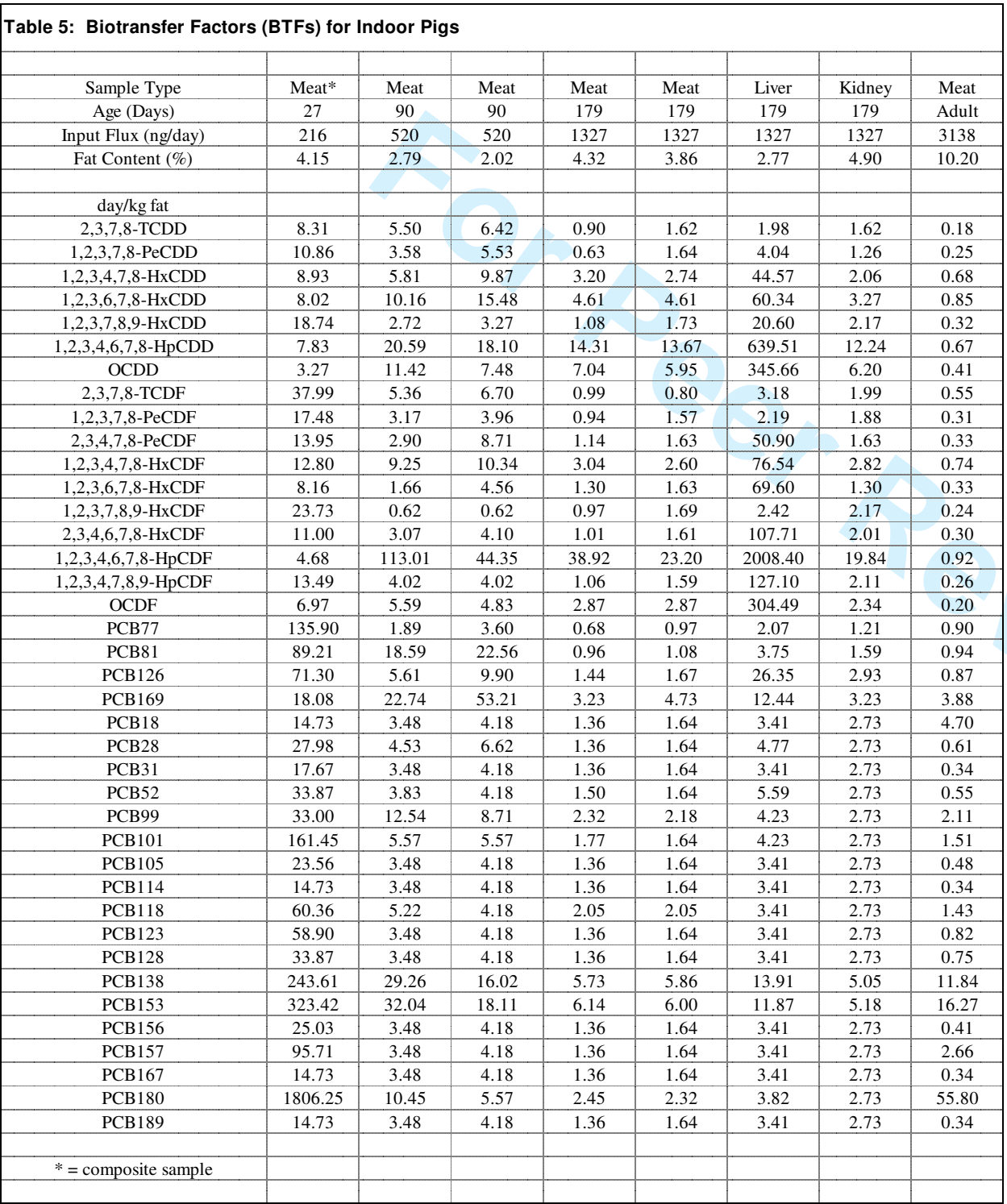


Table 6: Biotransfer factors (BTFs) for selected PCDD/F and PCB congeners in the indoor pig rearing programme

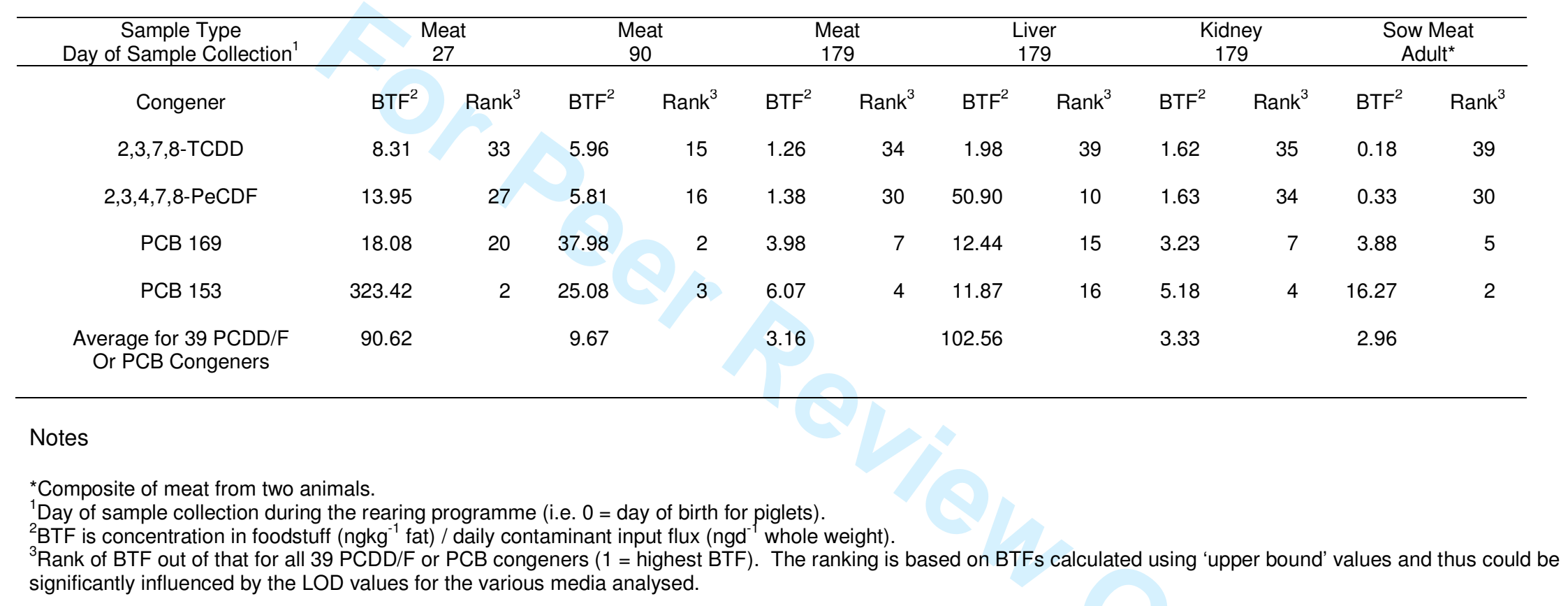

